\title{
ИЗ АРХИВА
}

\author{
С.И. Великовский
}

\section{СВОБОДА НЕПРИКАЯННЫХ}

Великовский С.И. В поисках утраченного смысла. Очерки литературы трагического гуманизма во Франции / С.И. Великовский. СПб.: Центр гуманитарных исследований, 2012. 271 с. С. 119-161.

$\mathrm{H}$ еотвязная память о душевной бездомности, отторженности от мирового Разума, «священного» или «естественного», и столь же неотвязная забота обзавестись другим «домом» для личности, который бы держался без предположения о вселенском «благоустройстве» и тем не менее обеспечивал ей подобие душевного спасения, - обе эти створки трагического гуманизма находятся у Мальро в постоянной работе, дополняя и уравновешивая друг друга. Стронутая с места «смыслоутратой» и повергнутая в крайнее беспокойство, мысль здесь старается соблюсти перепроверяющесдвоенный ход на каждой петле своего поиска, и ее настороженный спор с самой собой всякий раз не исчерпывает себя полностью, разомкнут в бесконечность своего возобновления. Когда же мышление устроено так, что тяготеет не к сравнительно нежесткому лирическому философствованию, а скорее к линейной развертке доводов из единого основания, оно склонно переносить упор преимущественно на какую-нибудь одну сторону дела, отодвигая вторую на свои обочины, удерживая в поле внимания лишь постольку-поскольку.

Во многом шедшие по стопам Мальро, но, в отличие от него, отнюдь не самоучки в философии, искушенные (хотя и неодинаково) в картезианском умении, Сартр и Камю как раз и осуществляют, каждый по-своему, подобное перераспределение света и тени. На первых порах, почти одновременно начав свой писательский путь, один во Франции, другой в Алжире, и издалека опознав друг в друге собратьев по «смыслоутрате», они сближаются в годы Сопротивления. Но довольно скоро обнаруживают пристрастие к разным слагаемым трагического гуманизма и извлекают из схожих посылок достаточно несхожие следствия. В 1951 г. их нашумевший спор и личный разрыв закрепляют это несовпадение бывших единомышленников.
Оба отправляются от бытийной неукорененности жизнечувствия, и оба хотели бы посильно укоренить его заново в какой-нибудь подходящей почве. Однако сосредоточенный изначально и прежде всего на непоправимой зыбкости положения отдельной личности, на ее безоговорочной свободе, Сартр, даже заподозрив со временем, что не все тут ладно, вынужден довольствоваться «заземлением» относительным, растяжимым до двусмыслицы. Камю, со своей стороны, в молодости тоже не чужд искусу такой свободы. Но затем, справедливо найдя ее своеволие крайне опасным, он жаждет прислониться к чему-то совершенно безусловному - к устойчиво-однозначному долгу. В результате прежние соратники расходятся очень далеко. К концу своей внезапно оборвавшейся жизни Камю удостаивается почестей совестливого блюстителя правосознания и нравственности западной цивилизации. Сартр же сегодня вдохновляет ее безудержных ниспровергателей из кружков левацкого революционаризма.

\section{1}

В театре середины XX в. иногда выделяют «театр представления» и «театр переживания». Следуя духу этого различения, театр Жан-Поля Сартра можно назвать «театром обсуждения». Каждая из его пьес ${ }^{1}-$ очередная встреча на подмостках Сартра-мыслителя, создавшего самостоятельную разновидность «философии существования» (экзистенциализма), и Сартра - политического публициста. Возникшая на пересечении этих двух ведущих (помимо потускневшего с годами романического творчества) линий его деятельности, смыкающихся в эссеистике, хотя и не всякий раз туго увязанных между собой, спектакль

\footnotetext{
1 Для настоящего очерка взяты те пьесы Сартра, где «смыслоискатсльство» трагического гуманизма выдвинуто в центр. Более полный обзор драматургии Сартра можно найти к статье: Бачелис Т. Интеллектуальные драмы Сартра («Современная зарубежная драма»). М., 1962), а также в моем послесловии к кн.: Сартр Ж.-П. Пьесы. М., 1967. - В дальнейшем re пьесы, переводы которых вошли в это издание, цитируются по нему, в остальных случаях по французскому собранию драматургии Сартра: Sartre Jean-Paul. Theatre. P., 1962.
} 


\section{Филология: научные исследования 1 (09) • 2013}

по пьесе Сартра всегда откровенно философичен и всегда более или менее публицистичен. Притча и памфлет - два крайних полюса, между которыми он колеблется, в обоих случаях оставаясь подчеркнуто интеллектуалистским, приглашающим зрителя дополнить непосредственный «наивный» отклик углубленным размышлением.

Думать в театре Сартра приходится всерьез и о серьезном. Не о мелочах житья-бытья, не о досадах и неурядицах, одолевающих на службе и дома, а о том, с чем не обязательно сталкиваешься повседневно, но над чем стоит порой ломать голову, коль скоро ты одарен разумом. Пытка мыслью - обычное состояние личности в пьесах Сартра, тут почти все на дыбе неумолимого «быть или не быть». А произнося свое «да» одной из возможностей, не просто сохраняют жизнь или подписывают себе смертный приговор, но закладывают краеугольный камень мировоззренческого сооружения со своей онтологией и вытекающей из нее нравственностью. Лицом к лицу с вселенной, историей, государством, веком, когда связь времен распалась так, что надежд соединить ее накрепко вроде бы нет, человек своим выбором и порой единственным поступком решает и собственную судьбу, и судьбу других, многих. Огромная, подчас непосильная душевная ответственность ложится на его плечи. Ведь выбрать линию своего поведения, а стало быть - выбрать себя самого, смысл своей жизни, волей-неволей означает попытку придать тот или иной смысл жизни окружающих, подтолкнуть и их на предпочтенный путь. В конечном счете добавить от себя желательный - пусть малый - оттенок к тому, в чем усматривается смысл жизни всего человечества.

Конечно, ход земных дел может ни капельки не измениться от этого вмешательства, просто сметая с дороги упрямую человеческую пылинку. Но перед собственной совестью - поистине последним судьей там, где нет ни Божьего промысла, ни его мирских замещений, - она достойна именоваться личностью лишь тогда, когда, вопреки своей хрупкости и смертности, отстаивает свою правоту. В этом ее всепоглощающая страсть. Не просто буря переживаний, нахлынувших невесть откуда и почему, но выношенная, выстраданная убежденность. Чувство, заряженное мыслью и ставшее призванием. Сартр, по его словам, через головы своих относительно близких предшественников, драматургов бытового и психологического театра, хочет вернуться к урокам XVII в., к отцу французской трагедии Корнелю, и еще дальше в глубь прошлого - к заветам древнегреческих трагиков. Упорство и безумие, нежность или мужество, писал он в своего рода театральном манифесте «Ковать мифы» (1946), — «это порыв чувств, истоки которых в недрах нашей души, и в то же самое время - выраженное с неколебимой волей утверждение определенной системы ценностей и прав, таких, как права гражданские, права семейные, личные моральные нормы и нормы коллективной этики, право убить другого, право открыть человеческим существам глаза на их достойный жалости удел».

В том, что полновластным хозяином личности назначается воля, управляемая интеллектом, ощутим намеренный вызов почвенной мистике. Потакание нутряным вожделениям захлестывало страны Запада в пору, когда рационалист Сартр вступал на философе ко-литературное поприще, - годы поставленной на поток фашистской обработки мозгов ради изготовления полчищ лихо марширующих и «думающих» по команде роботов. При всех своих несогласиях со старым просветительством, Сартр наследует его первоочередную обращенность к самостоятельному разуму, благодаря которому человеком движет не слепое наитие, а осознанная решимость.

Нужды тела при этом тоже не оставлены в небрежении. Сартр в своем театре (не говоря уже о прозе) на редкость откровенен, когда речь заходит о терзаниях и запросах плоти. Не брезгует он и впрямую физиологией. И это проступает даже на уровне слога - в сплаве языка мускулистого, изощренно отточенного в передаче оттенков мысли, подчас эллиптического, с просторечием, площадной вульгарностью, вплоть до крепких словечек из арго. И тем не менее «отелесненный» таким способом аналитизм не лишен своих пробелов: если считать (вслед за Платоном), что человек, так сказать, «трехсоставен» - рассудок, душа, тело, - то у Сартра, особенно раннего, ослаблена чуткость к среднему звену. За редкими исключениями оно как бы пропущено. Душевной многомерности, наследственных и благоприобретенных привычек, неповторимых психологических оттенков, житейского своенравия, исторических примет - короче, своего особого характера - действующим лицам в пьесах Сартра не то чтобы вовсе не дано, но он не столь уж важен. Прошлое, в недрах которого и вызревает характер, вообще их редко подталкивает. Чаще их словно «вытягивает» будущее. Сначала наметка самих себя завтрашних, затем образцы жизненной позиции, отлитые поступком, они - творения своего собственного ума: «обнаженная воля, чистый и свободный выбор, в котором страсть и действие неразделимы... Они и различаются между собой не так, как трус отличается от скряги и скряга от храбреца, а так, как разнятся и сталкиваются поступки, как одно право вступает в конфликт с другим» («Ковать мифы»). В более позднем театре Сартра своеобычность лиц бывает иногда 


\section{Из архива}

прорисована подробнее, выпуклее, но и здесь она все-таки только набросок характера.

Выбор себя тем или другим, самосозидание через поступок не совершается, конечно, в безвоздушной пустоте - тут первостепенная важность отводится ситуации, предлагающей с самого начала несколько выходов из нее, веер жизненных решений. В театре характеров ситуация тоже занимает далеко не последнее место, но там она обычно складывается постепенно, вытекая из их особенностей и взаимоотношений. И как именно ей обернуться, во многом зависит от них самих. У Сартра она скорее задана как лобовой вызов обстоятельств, нуждающийся в безотлагательном ответе, и есть пучок возможностей, одна из которых предпочитается. Свобода недовоплощенная, «проект» личности претворяется по ходу обдуманного, внутренне взвешенного и вслух проговоренного определения позиции — в личность воплощенную, состоявшуюся, действительно и весомо присутствующую в мире.

Необходимая для этого острая ситуация поэтому не просто внешняя обстановка, рамка происходящего, но основной рычаг пьесы Сартра, считающего свой театр прежде всего «театром ситуаций». Последние могут быть с виду весьма непритязательными, порой даже сводиться к случаю из газетной хроники. Однако они неизменно повернуты и толкуются так, чтобы «освещать самые существенные стороны человеческого удела» («Ковать мифы»). А тем самым получают нагрузку «мифа».

Понятно, что атмосфера внутри этой малой клеточки, призванной воспроизвести коренные основы жизнеустройства, предельно сгущена, раскалена до критической точки и чревата катастрофическим взрывом. Но чем ситуация ближе к «пограничной» - ставящей тех, кто в нее попал, перед угрозой гибели, - тем строже, честнее измерена их настоящая ценность, тем подлиннее они проявляют себя.

Разомкнутая в безбрежность бытия своей притчевой философичностью, ситуация в театре Сартра открыта и в другую сторону - к сидящим в зале. Они настойчиво приглашаются смотреться в нее как в зеркало, а не воспринимать как картину. Зеркало поставлено с нескрываемым расчетом так, чтобы зритель, потрясенный событиями, которые разыгрываются на подмостках, не был заодно и поглощен ими всецело, до беспамятства, до отключения от собственной жизни. А наоборот, был прямо-таки вынужден вновь и вновь возвращаться к себе, к своим помыслам и поведению, только отныне - с меркой более крупной и ответственной. Поэтому театральное представление по Сартру, даже когда оно протекает в глухом заточении меж четырех стен, допускает и провоцирует подстановки из нашего - моего и моего соседа по залу - духовного и житейского багажа. И чем отчетливее сквозь происшествие прорастает «миф», тем успешнее он срабатывает как катализатор мыслительной энергии, таившейся под спудом дневных хлопот в сознании тех, кто вечером пришел в театр. В попытках встряхнуть, побудить к требовательной самопроверке и сплотить умы, полчаса назад разрозненные, вокруг того, что касается или может коснуться решительно каждого, - назначение спектакля. И в этом «обряде» соразмышления многих, когда они одновременно протягивают мысленную нить от сугубо личного и житейского к бытийно-всезначимому, сохраняется, в глазах Сартра, немало от древнего ритуального зрелища.

«Обрядовость» сартровского театра - не в ходульной высокопарности. Не терпит он и обволакивающей задушевности домашней беседы, полунамеков, «обратных ходов», когда сказанное противоположно действительно имеющемуся в виду. Он ищет всегда и нередко добивается рабочей сосредоточенности совместно мыслящих зрителей. Схватка двух прав, двух правд - его пружина; поведенческий выбор в зависимости от самоопределения во вселенной и истории - его средоточие ${ }^{2}$; не ведающая для себя ничего запретного напористо-безжалостная аналитичность - его стихия.

\section{2}

Когда прославленный французский постановщик Шарль Дюлен в июне 1943 г. в занятом гитлеровцами Париже показал первый спектакль по Сартру «Мухи», зритель безошибочно улавливал в этой обработке древнегреческого мифа об Оресте, мстящем за убийство своего отца Агамемнона матери Клитемнестре и ее сожителю Эгисфу, злободневное иносказание, призыв к непокорству. Воображение легко втягивалось в русло подстановок: Эгисф - это нацисты, хозяйничающие в

\footnotetext{
2 Нацеленность театра Сартра на выработку нравственно-поведенческих ориентации личности определяет место этого жанра в его творчестве. Обещанное философом в конце трактата «Бытие и небытие» продолжение в виде экзистенциалистской этики так никогда и не было написано, однако последняя вполне аутентично может быть сконструирована по его пьесам (см. опыт такого сводною описания: Verstraeten P. Violence el ethique. Esquisse d'une critique de la morale dialectique a partirdu theatre politique de Sartre. P., 1972). Впрочем, один ил учеников Сартра еще четверть века назад предпринял и теоретическую экспликацию этики, отправляющейся от сартровской онтологии, и рукопись не вызвала возражений Сартра. Книгой эта объемистая работа вышла, однако, лишь недавно: Gorz A. Fondementspourune morale. P., 1977.
} 


\section{Филология: научные исследования 1 (09) • 2013}

покоренной стране, Клитемнестра - их пособники из Виши, вступившие в преступную связь с иноземными насильниками, тираноборец Орест - один из первых добровольцев Сопротивления, подающий соотечественникам пример свободы, его сестра Электра французы, мечтающие о низвержении кровавых правителей, но колеблющиеся и не дерзающие взяться за оружие.

Все это, несомненно, подразумевалось в «Мухах». Дело только в том, что подобное прочтение, затрагивая лежавший на поверхности пласт «Мух», далеко не исчерпывает этой притчи для подмостков. Вернее, для Сартра сами исторические потрясения тех лет особенно разительное напоминание о том, что он, как и Мальро и примерно в том же смысле, называет «человеческим уделом». «Жестокие условия нашей битвы, - писал Сартр в статье 1944 г. «Республика молчания», - сняв все румяна и покровы, сделали наконец самой нашей жизнью то невыносимое, душераздирающее состояние, которое именуется уделом человеческим. Изгнание, плен, особенно смерть, ловко замаскированные от нас в пору благоденствия, оказались теперь предметом наших повседневных забот; мы постигли, что это вовсе не случайности, которых можно избежать, ни даже опасности постоянные, но все-таки привходящие - нет, нам пришлось взглянуть на них как на наш удел, нашу судьбу, как на глубинные предпосылки человеческого существования» ${ }^{3}$. Театральный пересказ древнего предания об Оресте и выполнен Сартром в этом двойном ключе: как перекличка с тем, что пережито французами в годы нашествия, но перекличка, которая понуждает расслышать в сегодняшних бедах отголоски извечного людского проклятия. «Мухи» — столько же иносказание о Франции под сапогом захватчика, сколько и миф об одной из граней «человеческого удела».

Отсюда - двойной масштаб, принятый Сартром и позволяющий ему постоянно переключать все, что происходит или говорится в трагедии, из плоскости иносказательно-исторической в плоскость философствования об «уделе» и обратно. Отсюда - двойной завет, брошенный Орестом в зрительный зал: одновременно агитационный лозунг и мировоззренческое «исповедую». Отсюда — два врага, которые даны Оресту: Эгисф и Юпитер, тиран земной и тиран небесный, диктатор и бог.

Жители города Аргоса, где царит Эгисф со своей пособницей Клитемнестрой, не просто забиты и напуганы. Они еще и жертвы не лишенного хитрости внушения: изо дня в день их уверяют, что они вполне

3 Sartre Jean-Paul. Situations III. P., 1949. P. 10. заслужили свой позор и потому обречены на нескончаемые угрызения совести. Когда-то, заслышав доносившиеся из дворца крики убиваемого Агамемнона, они заткнули уши и смолчали. Эгисф ловко раздул их стыд за тогдашнюю трусость, превратил его в первородный грех, объявив покаяние личной добродетелью и гражданской доблестью. Духовным оскоплением подданных Эгисфа пятнадцать лет кряду занимается пропагандистская машина, вдалбливающая в головы мысль о повальной и неизбывной вине. В ход пущено все, от оружия стражников до проповедей жрецов, от напавших на город мух — материализованных укоров нечистой совести, до наглядных пособий в виде измазанного кровью идола, водруженного на уличных перекрестках. Не обошлось и без назидательного личного примера - самой Клитемнестры, чьи основополагающие, «конституционные» прегрешения всем уже навязли в зубах и которая теперь, потеряв слушателей среди знающих все наизусть горожан, выворачивает грязное белье своего прошлого перед первым приезжим. И как апофеоз государственного покаянного культа: раз в год ритуальные бдения на празднике мертвецов, когда аргосцы, поголовно впадая в мазохистский экстаз, предаются исступленному самопоношению.

Вечно трепещущим и вечно сгорающим от стыда горожанам Эгисф кажется грозным владыкой. Одного его жеста довольно, чтобы смирить взбудораженную толпу. На деле же он пугало, устрашающая маска, напяленная на живой труп, - еще больше мертвец, чем истлевший в могиле Агамемнон. Сам по себе он уже давно превратился в обратное отражение страха, который внушает своим подданным. Властелин этих трясущихся рабов, он сам жалкий раб, порождение их испуга. Все его «заслуги» - ловкость шулера, скрывшего от них своим кривляньем один простой секрет: они свободны. Свободны поджечь с четырех концов его дворец, свободны избавиться от боязни и изуверских покаяний. Достаточно, чтобы эта истина озарила ум хрупкого юноши Ореста, и Эгисфу ничего не остается, как позволить проткнуть себя мечом, словно чучело.

Вылепив этого гиганта на глиняных ногах, Сартр подчеркивал, что его соотечественники, будучи ответственны за случившееся с Францией, вместе с тем располагают возможностями освобождения. Важно раскрепоститься внутренне, уверовать в себя. Да, они виновны в том, что оказались слишком робки и слабы, дали себя побить. И еще более виновны те из них, кто принял поражение за Божью кару и благословил длань карающую. Сартровское «mea culpa», в отличие от стенаний пораженцев, будило, а не усыпляло, звало взяться 


\section{Из архива}

за оружие, вместо того чтобы посыпать голову пеплом. Рискуя преуменьшить мощь фашистских дивизий, расквартированных по городам и селениям страны, Сартр своими «Мухами» старался убедить: здесь и сегодня, а не в отдаленном будущем нам по силам разбить оковы, взломать застенки, Францию порабощенную превратить во Францию мстителей.

За этим очевидным уроком патриотической гражданственности в сартровских «Мухах» кроется, однако, и другой, более широкий и не столь легко уловимый. Ведь в конце концов Эгисф со всеми его охранниками только марионетка в руках паясничающего громовержца Юпитера. Он - земное орудие надмирной тирании, инструмент, который выбрасывают, когда тот изнашивается. Эгисфы приходят и уходят. Юпитеры остаются. Опустошенный, уставший жить Эгисф чуть ли не сам идет на заклание. Юпитера одолеть куда труднее. Электра испытала его железную хватку в ночь после расправы над отчимом и матерью, когда вместе с братом укрылась в храме Аполлона и здесь поняла, что ей недостанет мужества оправдать по совести собственный поступок. А между тем кто, как не она, перенесенными ею с детства унижениями заслужила право мстить? И кто, как не она, беззащитная девочка в белом платье, - бросив этим нарядом невинности вызов всему городу, одетому в траур по случаю праздника мертвецов, и потерпев поражение, - отдала себе отчет в том, что необходимо прибегнуть к насилию? «Зло одолеешь лишь злом», и такое «зло» есть добро. И вот, дождавшись свершения своих чаяний, Электра вдруг почувствовала себя словно обокраденной. Да, лишь в ночных грезах лелеяла она свои мстительные замыслы, рисовала себе смерть ненавистной четы, и игра в жестокую надежду стала для нее заменой жизни. Теперь уже Юпитеру ничего не стоит убедить ее в том, что, перейдя от слов к делу, она сделалась преступницей и, подобно матери, навек обречена замаливать грех. Вместо того чтобы самой решать, справедливо ли ее мщение, Электра, не умеющая жить без санкции извне, прибегает к заповедям о предустановленном кем-то свыше добре и зле и тем передоверяет носителю божественной воли право осудить ее или оправдать. И коль скоро Юпитер, разыгрывая добренького дядюшку, тем не менее выносит ей бесповоротный приговор за матереубийство, Электра поступает точно так же, как когда-то, после гибели ее отца, поступили ее сограждане: благословляет пытку раскаянием и готова до скончания дней волочить за собой угрызения совести, словно каторжник ядро. Душевная слабость заставляет ее бежать от свободы, как от чумы.
Случай с Электрой очерчивает те границы, которые уже во втором, бытийном измерении «Мух» необходимо перешагнуть, дабы стать поистине свободным. Мало низвергнуть земного диктатора, надо низвергнуть диктатора небесного в собственной душе, надо признать самого себя высшим судьей всех своих поступков. Спор Ореста с Юпитером - философская сердцевина пьесы и призван обосновать неотчуждаемое право личности выбирать свой способ действий независимо и даже вопреки любым сверхличным предначертаниям извне, чьи бы уста их ни возвещали человеческие или божеские.

Спор этот завязался задолго до того, как противники сошлись перед Электрой во всеоружии своих доводов. Сразу же после праздника мертвецов Орест на душевном распутье, колеблясь между желанием поскорее убраться из города и побуждением вступиться за справедливость, просил совета у всевышнего. И тотчас же его получил: по мановению руки Юпитера камень засветился в знак того, что Оресту лучше не вмешиваться, оставить в Аргосе все по-прежнему. Выходит, повелителю Олимпа любезен кающийся город с его мухами, убийцей на троне, культом виновности и особенно его страхами: ведь страх божий - залог благочестия, послушания, несвободы.

Оресту ясен теперь промысел небес - и он поступает наоборот. Он ни за кем не признает права отдавать ему приказы. Осуществив возмездие, он уточнит: «Я свободен, Электра... Я совершил мое дело. Доброе дело». Отныне у богов отнята привилегия решать что есть добро и что есть зло - человек решает сам. Отныне боги не указуют смертному его дорогу — он ее выбирает сам. Орест пренебрег всеми подсказками свыше, он не ждет оттуда ни помощи, ни совета. Ни перед кем, кроме самого себя, он не желает отчитываться. Свободу в ее полнейшей несвязанности он сделал краеугольным камнем своей морали.

В храме Аполлона, куда укрылись мстители, «небесный кормилец» Юпитер дает последний бой ускользнувшему из-под его власти нечестивцу, склоняя его вернуться на стезю послушания. И проигрывает окончательно и бесповоротно. Несмотря на то, что пускает в ход все: угрозы, увещевания, мелодраматические заклинания, космологическую казуистику. Довод «натурфилософский»: человек - частица мироздания, вовлеченная в его механику и обязанная повиноваться законам, управляющим всей природой. Довод «общественный»: благонамеренным жителям Аргоса мерзок отщепенец, опрокинувший заведенный в городе порядок, под крылышком которого они так удобно устроились, обратив расчесывание совести в усладу, и они ждут непрошеного «спасителя» при выходе из 


\section{Филология: научные исследования 1 (09) • 2013}

святилища, запасшись вилами и каменьями. Довод «семейный»: протяни руку помощи сестре, не нашедшей в себе сил снести бремя свободы. Довод отечески участливый, последний и едва ли не самый веский: заблудшей овце трудно, она не ведает ни отдыха, ни сна, опека заботливого пастыря сулит ей конец тревог. Все это разом обрушено на Ореста. Он же твердо стоит на своем: «Я есть моя свобода». Да, Юпитер - повелитель камней, звезд, морей, растений, животных, всего природного царства. Но он не владыка людей, коль скоро они открыли для себя, что свободны. И богу ничего не остается, как признать: «Пусть так, Орест, все это было предначертано. В один прекрасный день человек должен был возвестить мои сумерки. Значит, это ты и есть? И кто бы мог подумать это вчера, глядя на твое девичье лицо?».

Провозвестник «сумерек богов» и пришествия царства человека, свободного от велений свыше, сартровский Орест прямо противоположен своему древнегреческому пращуру, Оресту Эсхила. Тот убил вопреки старому материнскому праву, но убил по совету божественного оракула и во имя богов, только других - молодых, покровителей возникающей афинской государственности. Недаром мудрая Афина спасает его от эриний, хранительниц кровных уз материнского рода, оправдывая месть за отца. Орест Сартра не домогается ничьих оправданий, его свобода поистине самостийна и есть выпадение из всякого бытийного лона. Трагическое этой очередной отходной по нравственности, привыкшей оглядываться на внеличные, божественные предначертания, имеет совсем другие истоки.

Они приоткрываются, если учесть, что мишень обстрела со стороны Сартра, конечно же, не древнегреческий пантеон небожителей. Повелитель аргосских мух с равным успехом может сойти за христианского, иудейского, мусульманского и любого другого бога. Они одинаково связывают по рукам и ногам верующих, допуская свободу до тех пор, пока она не выходит за рамки веро-откровенных заповедей, где бы они ни были записаны - в Ветхом Завете, Евангелиях или Коране. Орест покушается на устои всякой священно-вечной, предустановленной морали, которая строит свой кодекс на признании дарованного «творцом» мирового «благоустройства». Принцип нашего действия не дан от века, не есть предварительная посылка для наших поступков и их нравственной оценки. Или, переходя на философский язык Сартра: сущность человека не предшествует каждому отдельному существованию, а есть конечный результат всех совершенных за жизнь поведенческих выборов. Вера предлагает аксиомы добра и зла, покоящиеся на допуске относительно упоря- доченности «творения», - для Сартра они подвижны, зависят от самой личности, свободной самостоятельно их определять.

Следует только заметить, что богоборец Орест, в полном согласии с тем особым безбожием, которое ставит знак равенства между «промыслом» и «смыслом», между закатом веры и «смыслоутратой», отмежевывается не от одних мистиков. Ведь если отнять у Юпитера его фокусы-чудеса и изъять у него претензию быть создателем и управителем мироздания, то в нем придется, по замыслу Сартра, узнать себя по крайней мере всем тем, для кого человек органически включен в космос, в упорядоченность, законосообразность сущего. Всем тем, для кого познание необходимости в ее становлении скажем яснее: «диалектики природы» - отнюдь не безразлично для свободы. Прозрение Ореста как раз и состоит в том, что он должен оставить надежды на поддержку извне, и потому ему не во что вникать и не с чем сообразовываться как во вселенной - мире вещей, так и в городе - историческом мире людей. На всем белом свете он навсегда «чужак», «вне природы, против природы, без оправданий, без какой бы то ни было опоры, кроме самого себя. Но я не вернусь в лоно твоего закона: я обречен не иметь другого закона, кроме моего собственного».

Подобная свобода не есть познанная и использованная законосообразность, а вызов законосообразности, вплоть до ниспровержения всякого естественного природного или исторического - сцепления причин и следствий. И провозглашение безоглядной воли единственным побудителем личности. В этом смысле «Мухи» - не трагедия в ее издавна привычном обличье. «Мне отмщение, и аз воздам», - громко возглашала всегда своевольному или заблуждающемуся смертному трагическая судьба, как бы она ни именовалась древним роком, библейским Богом, разумом бытия или движением истории. «Когда свобода вспыхнула однажды в душе человека, дальше боги бессильны», выдает свой секрет сартровский Юпитер, эта Судьба, как будто теряющая былое могущество, В «Мухах» нет ни зловещей трагической иронии, ни катастрофы и трупов под занавес: Орест опрокидывает классическую трагедийную коллизию и выходит победителем из поединка с грозным соперником. Не потому ли и трагедия Сартра об Оресте носит по-аристофановски комедийное название: «Мухи»?

Но в таком случае отчего побежденный громовержец вовсе не спешит складывать оружие? Только ли оттого, что сломленная и предавшаяся покаянию Электра по-прежнему остается в сетях небесного ловца душ? Отчасти, конечно, да, но этим дело не исчерпывается. Проницательный небожитель не по- 


\section{Из архива}

ставил крести на взбунтовавшемся Оресте, прекрасно зная, что тот избрал ухабистый путь, где легко снова споткнуться. Ведь твоя свобода, роняет он пророчески Оресту на прощанье, - тяжкое бремя, «отлучение», «парша» изгнанного из стада; и аргосцы вряд ли обрадуются подарку своего незваного благодетеля. «Да, ты прав, - вынужден согласиться Орест. Если и для них нет надежды, почему я, утративший ее, не должен с ними поделиться отчаянием?.. Они свободны, настоящая человеческая жизнь начинается поту сторону отчаяния». Вот, оказывается, какова та последняя истина о человеческом уделе, которую, по Сартру, обнажило перед французами гитлеровское нашествие и которую он вложил в древний миф об Оресте. Каждый дерзнувший приобщиться к свободе постигает, что он одинок, лишен благосклонного покровительства, вытолкнут из бытийного уюта и, отчаявшись в поддержке откуда бы то ни было, приговорен прокладывать жизненную дорогу на собственный страх и риск. Орест, чужестранец в начале, попавший в Аргос не ведая, что он отсюда родом, и добровольный изгнанник в конце, так и не пустивший корней в родную почву, - это и есть неприкаянный во веки вечные сартровский ревнитель свободы, взваливший на плечи всю тяжесть скитальчества в дебрях бытия. Снятие трагедии в «Мухах» на поверку есть перемещение источника трагического извне - вовнутрь, в сокровенное ядро свободной личности. И суть этой переиначенной трагедии - в мучительной неуверенности обретения ценностных установок и смысла собственной жизни.

В самом деле, коль скоро личность «отлучена», предоставлена одной себе, то на что же ей положиться и чем наполнить свою свободу? Не исчерпываются же ее устремления сплошными «нет» - «нет» Эгисфу, «нет» Электре, «нет» горожанам, «нет» Юпитеру, «нет» природе. С другой стороны, откуда взяться «да», раз все окрест чуждо и свободе не на что опереться, нечем нравственно питаться и не к чему стремиться, кроме единственно самой себя. Сартр будет вновь и вновь пробовать выскользнуть из этого заколдованного круга. История Ореста открывает череду таких попыток, в лучшем случае дававших полуудачу.

Орест завязки «Мух» и Орест их развязки — два очень несхожих лица. У них даже имена разные: первого зовут Филеб, и Электра точно соотнесет с исполнением кары момент его «смерти» и «рождения» собственно Ореста. Да и сам Орест в трогательных словах простится со своей юностью: двойное убийство, отчима и матери, разрубит его жизнь пополам на «до» и «после». «До» обрисовывает его воспитатель: «Вы молоды, богаты и красивы, сведущи, как старец, избавлены от ига тягот и верований, у вас нет ни семьи, ни родины, ни религии, ни ремесла». Пока не воплощенная, невесомая «свобода-в-себе» этого просвещенного скептика - «свобода паутинок, отозванных ветром от сетей паука и парящих высоко над землей». «После» - это муж, обремененный грузом ранней зрелости: «Мы были слишком легковесны, Электра: теперь наши ноги уходят в землю, как колеса колесницы в колею... Мы отправимся в путь тяжелым шагом, сгибаясь под ношей». А между этими двумя состояниями, между свободой - «отсутствием» и свободой — «присутствием»- месть Ореста, его поступок, деяние. Первая, в глазах Сартра, — мираж и пособничество несвободе в виде уклонения от выбора, которое на свой лад тоже выбор. И лишь свобода деятельная, вторгшаяся в ход событий, принявшая чьюто сторону или восставшая против чего-то, подлинна «Моя свобода - это и есть мой поступок», - твердо проводит Орест знак равенства.

Но поступок, в отличие от простого намерения, всегда нечто меняет и создает, тем самым утверждая определенную нравственную ценность. Кровавое причастие Ореста тоже призвано не только утолить его жажду отомстить и укорениться в жизни. Оно затеяно, чтобы послужить и укором справедливости для аргосцев, вернуть им чувство собственного достоинства. И такое поучение-призыв от поступка Ореста исходит. Однако воздвижение на развалинах сокрушенных лжеценностей других ценностей, полагаемых истинными, неизбежно ограничивает в дальнейшем свободу очередных выборов верностью своему собственному прошлому. Рождение свободы, по Сартру, таит в себе опасность ее закрепощения - на этот раз самой собой. И когда Юпитер предлагает Оресту заменить Эгисфа на опустевшем троне, тот уже знает, что, согласившись, сделается рабом своего поступка и сделает снова рабами своих подданных. Из этой ловушки один выход: не дать уроку, преподанному однажды, застыть общеобязательной, сущностной нормой, отвердеть в заповеди. В прощальной речи перед горожанами Орест отвергает трон и скипетр, предпочтя долю «царя без земель и подданных». В довершение всех «нет» он словно произносит еще одно «нет» - своему же завоеванию.

Трагедия такой свободы, выбросившей за борт вместе с верой в «священное» доверие к любым сущностям, - в ее бегстве от собственной тени, в ее боязни задержаться хоть на миг и опредметить себя, отлиться хоть в какой-то закон. Опасаясь тайных пороков, которые могут возобладать, едва она задремлет и потеряет бдительность, она пытается спастись от грехопадения, воспитав в себе отвращение к власти. 


\section{Филология: научные исследования 1 (09) • 2013}

Только вот надежно ли это профилактическое самолечение? И если да, то какой ценой? Орест поначалу клялся перевернуть все в Аргосе вверх дном. И в конце он уходит, оставляя горожан почти в том же положении, в каком застал их по приезде. Все та же слепая кающаяся толпа. Клитемнестру заместила Электра, теперь похожая на мать, как одна капля воды на другую. Что до Эгисфа, то ловкий Юпитер наверняка что-нибудь придумает взамен. Столь тяжкий подвиг, столь громкие речи - и такой обескураживающий исход. Героический порыв Ореста не заражает аргосцев, а, скорее, парализует их сознанием своей с ним разницы. Им не дано просто взять и покинуть город. Исключительная судьба Ореста - не их заурядная судьба, его философические заботы - не их насущные заботы. Торжество смахивает на провал.

И это не случайно. По правде сказать, было бы чудом, если бы все сложилось иначе. С порога отметать законосообразность, то есть находящуюся во внутренне противоречивом развитии структуру мира, с которым имеешь дело, - это, спору нет, показатель мужества и проходит не вовсе бесследно для очевидцев. И все же, после первого отклика на впечатляющую броскость подобного бунта, само собой всплывает недоумение: а как тогда внедрять в этот самый мир свободу столь своенравную, что она ни с чем не хочет сообразовываться? Тем паче внедрять ее в городе, население которого видится тебе быдлом, загадочным и капризным: скоплением людей не менее аморфным, чем природа - скопление вещей. Созидатель, будь он освободителем или строителем, всегда по крайней мере, стихийно - предварительно исследователь. Он вникает в ту скрытую от поверхностного взгляда работу, что происходит в вещах и умах, зовется их законом и есть неоднозначное движение, которым стараются овладеть, исподволь направить в желательную сторону и заставить себе служить, от себя продолжив и дополнив, - словом, посильно приручить. Оресту же ведомы лишь застывшие противоположности: либо плоская одномерная упорядоченность, либо свобода - «бесполезная и произвольная (gratuite) страсть» (как определяется «существование» в писавшемся тогда же философском труде Сартра «Бытие и небытие»); одна решительно исключает другую. Но подобная свобода - полое «ничто», огульное и самодостаточное отрицание, все то же воплощенное «не», что и в «Тошноте». У нее почти что «нулевой» ценностный заряд и пониженная плодотворность. Все это подрывает, мистифицирует позиции Ореста. Он помышлял избавить горожан от гнета («люди, я люблю вас, я убил ради вас») — и с легкостью покидает их на произвол Юпитера, жре- цов, мучимой укорами совести Электры, преемницы Эгисфа и Клитемнестры. Он хотел получить права гражданства на родине, обзавестись своим «домом» на земле - и остается перекати-полем. Он жаждал дела - и удовольствовался жестом, героическим, но - жестом.

Примесь жеста вообще есть в каждом действии Ореста, извращая все, что бы он ни предпринял. Даже в самый «звездный» свой час он не может от этого избавиться и к делу - убийству Эгисфа - добавляет жест: убивает Клитемнестру. Расправа над матерью после смерти тирана никому не нужна, не оправдана даже исступлением момента, поскольку Орест заранее предупредил, что мстит с холодной головой. Лишний труп нужен разве что ему самому, чтобы сполна унаследовать всю преступность кровавого рода Атридов, взвалить на хрупкую и непорочную душу невыносимое бремя, которое бы сделало его наконец плотным, жизненно полновесным, значимым. Оресту крайне важно распрощаться с собой прежним, девственно-призрачным, которого никто не принимает всерьез, ни просто в расчет. Перестать казаться — кем-то быть. Пусть извергом - в городе, отравленном угрызениями совести, это вполне уместно, и чем чудовищнее злодейство - тем лучше. Орест настолько поглощен этим самоутверждением в глазах других, что волей-неволей превращает аргосцев в ошарашенных зрителей своих деяний - в простых посредников, с помощью которых он, «не связанный обязательствами от рождения», исключенный из общей жизни, присваивает ее теплые токи. Взоры других становятся для него магическим зеркалом, которое возвращает ему его жесты, но «очеловеченными», опаленными живой страстью, восторгом или ужасом - не все ли равно?

Однако заворожить публику еще не значит зажить одной с ней жизнью. Обитатели Аргоса, встречая Ореста бранью и улюлюканьем, на свой лад признают его заслуги возмутителя спокойствия, но не признают своим. И не пускают под свой кров, к своим очагам, в свое сердце. Их проклятия и, еще больше, их гробовое молчание - это, конечно, далеко не окончательный приговор его делу и не признак их полнейшей правоты. Но несомненно - свидетельство того, что ни завоевать для Аргоса свободу, ни завоевать себе место в его стенах Оресту не удалось. В утешение ему остается одно - наверстать в вымысле потерянное в действительности. Вырвать себя из повседневно-житейского ряда, где он потерпел поражение, и предстать перед всеми в ореоле легендарного искупителя. Под занавес, прежде чем навсегда покинуть не принявший его город, Орест рассказывает толпе слушателей предание о крысолове с волшебной флей- 


\section{Из архива}

той, некогда спасшем Скирос. Он как бы приглашает отнести легенду к только что случившемуся, лишь заменив крыс на мух. Ему, однако, невдомек, что замена здесь, если вдуматься, по меньшей мере спорна, граничит с логической неувязкой, хотя Орест волею Сартра действительно уводит за собой рой мух. Но ведь мухи - угрызения совести, которых тираноубийца не признает и не собирается испытывать. И место им скорее в городе, где по-прежнему будет царить дух повального раскаяния, который наверняка станет насаждать Электра - сломленная, удрученная виной своего соучастия в убийстве матери и отчима, преисполненная намерений предаться замаливанию грехов. Заключительное самоувенчание Ореста с помощью древней легенды - последняя попытка очаровать отвергших его сограждан, внедриться не мытьем, так катаньем пусть не в их дальнейшую жизнь, на худой конец - в их умы. Увековечить себя в их памяти и тем спастись от забвения и чувства собственной недостаточности способом, близким к тому, каким надеялись «спастись» от небытия «завоеватели» у Мальро, норовя оставить «след на карте», или каким у самого Сартра спасался Рокантен в «Тошноте», когда решал приняться за книгу о том, что не есть «существование».

$\mathrm{C}$ «Мухами» сартровский искатель и мученик свободы впервые вступает на поприще истории. Но пока что он подвизается здесь как пришелец со стороны: душеспасительные его чаяния совсем иного рода, чем утех, кто пребывал и пребудет тут всегда и не мыслит себе другой жизни. Расплата за недоразумение не заставляет себя ждать: очень многое из того, что в подобных случаях задумано как дело, оборачивается игрой - пусть не вовсе мнимым, но и не слишком результативным вмешательством в историю.

Кроме того, упование на самодостаточную и «беззаконную» - исключительно внутри себя черпающую все, что ей необходимо для жизнедеятельности, - одиночную свободу обречено на каждом шагу опасно оступаться. Оно проваливается в ямы своеволия постольку, поскольку затрудняется обеспечить себе общезначимые различители добра и зла, обзавестись сколько-нибудь надежной «санкцией» для поступков в пустоте отсутствия ее на «святом месте». Коварная шаткость этой бытийной покинутости воочию вскрывается при проверке историей, когда серьезные испытания, сделавшись участью многих, заставляют усвоить, что нравственное лицо «самости», отпавшей от прежнего средоточия духовных смыслов, может быть соблюдено лишь в том случае, если она неукоснительно соотносит себя с превосходящим ее ценностным мерилом.
Сартр был слишком чуток к самообманам «ловчащей совести», чтобы рано или поздно не заметить здесь подвоха. И тогда он обмолвится, что, доведись ему взяться за «Мух» теперь, он бы задержал Ореста в стенах города, где призыв к свободе, дабы он не оказался звуком пустым, надо еще и воплощать. Как бы то ни было, в дальнейшем в театре Сартра — да и не только в театре - сквозит упорная потребность сопоставить чужестранца в истории с ее коренными обитателями. А для этого выделить из толпы, безликой в «Мухах», проработанные с возможным тщанием лица и дать им самим высказаться.

Преемники странствующего рыцаря свободы Ореста в последующих пьесах Сартра всякий раз будут иметь рядом с собой таких спутников, тяжело ступающих по земле и сбивших в кровь об нее ноги. Спор в «Мертвых без погребения» (1946) и «Грязных руках» (1948) выявит крепость этих работников от истории и слабости спасающихся в ней заезжих гостей. Но когда Сартр в «Дьяволе и Господе Боге» (1951) попытается подстроиться к правде первых, признанной им гораздо прочнее, он вольно или невольно перестроит ее в духе той зыбкости, какой страдала правда вторых. И тем докажет так и не изжитую им приверженность к свободе бытийно неукорененных.

\section{3}

Канвой для «Мертвых без погребения» Сартру послужил не давний миф, а случай из совсем недавнего прошлого - дней партизанского Сопротивления во Франции. Зрителю больше не надо было добираться до философского урока кружным путем легенды.

Пятеро схваченных партизан заперты на захламленном школьном чердаке. Внизу, в классной комнате, их поочередно пытают, чтобы добиться сведений о том, куда скрылся их командир. В отличие от товарищей, погибших накануне, им отведено несколько «лишних» часов, когда ничего не осталось, как думать о предстоящих пытках и казни. О себе в свете неминуемой смерти. Заточенные в четырех стенах больше ничем не могут быть полезными тем, с кем прежде сражались локоть к локтю. Им даже утаивать на допросах нечего, поскольку они действительно не знают, где теперь их командир. Они выбыли из жизни. Исчезли, развеялись все заботы, еще вчера рисовавшиеся столь важными, - каждый очутился наедине с мыслями о споем смертном уделе. Блажен тот, кто замертво упал однажды на ходу, не успев толком об этом задуматься. Блажен и слеп - ему ведь так и не довелось узнать про себя все до конца.

И все-таки чердак смертников у Сартра не герметически закупоренная колба. Жизнь врывается сюда с го- 


\section{Филология: научные исследования 1 (09) • 2013}

лосом радиодиктора, передающего сводки о положении на фронте, она возникает в воспоминаниях о недавних боях и далеких родных, в гаданиях о завтрашнем дне тех, кому суждено уцелеть, дождаться победы, до которой уже совсем близко. А главное - жизнь направляет к отрезанным от всего света пленным своего посланца, их случайно попавшего в облаву, но не узнанного карателями командира Жана. И если его не выдадут, он вернется к своим и приведет с собой отряд мстителей. Словом, и жертвы и палачи, запертые на очной ставке с неизбежной гибелью, вынуждены то и дело менять масштаб своего безысходного «здесь» и «сейчас» на масштаб крупного исторического столкновения, в которое они с разных сторон вовлечены. Переключение из одной системы отсчета в другую, их сопоставление и взаимное опровержение, и дает «Мертвым без погребения» принцип построения и одновременно интеллектуальный нерв.

Скальпель беспощадного сартровского анализа жесток даже и для видавших виды в безднах затравленного сознания. С хладнокровием хирурга он анатомирует пять душ, втянутых в поле смерти. В огромной литературе о фашистских застенках не часто встречается такое почти кощунственное вскрытие черепной коробки смертника. Близость пыток и последнего часа сдирает все покровы, заставляя каждого обнажить настоящее, подчас ему самому неведомое нутро.

Из всех пятерых один только старый революционерподпольщик, грек Канорис, не делает для себя никаких открытий - и тюрьмы, и пытки, и свидание со смертью для него не внове. Зато мудрая прозорливость ветерана позволяет именно ему исчерпывающе обозначить сложившееся положение: «Все, что происходит в этих стенах, не имеет значения. Надеяться или отчаиваться это ничего не даст». Пусть каждый поступает так, чтобы поменьше страдать, - способы безразличны. Безразлично, трус ты или подвижник, гордый венец творения или тварь дрожащая. Всеуравнивающее безразличие всех различий - вот в чем предпосылка той подлинности, какую обретает всякий, вступивший в зону, пограничную со смертью.

Случайный арест Жана, тоже посаженного на чердак, опрокидывает первоначальную ситуацию. И ставит под вопрос подлинность самой этой подлинности. Теперь заключенным есть о чем молчать. Восстановлена порванная было связь с большим миром, они снова защищают на своем малом плацдарме то, ради чего раньше ходили в атаку под пулями. Выдержать пытки надо уже не просто для того, чтобы в смертный час сохранить к себе уважение, а еще и заботясь о тех шестидесяти партизанах, товарищах по оружию, которых предупредит и поведет Жан. Только что рисовавшиеся равнозначными поступки получают осмысленность, становятся ценностно значимыми.

И это дает «трусу» Сорбье, стойко переносившему опасности партизанской жизни, а теперь боящемуся предательской немощи своего тела, силы узнать, чего он действительно стоит. И погибнуть героем, выбросившись из окна, но ничего не выдав истязателям. Это делает страх Франсуа, еще почти мальчика, опасным не для него одного. Это перечеркивает и раздумья Анри, одного из сартровских бытийно неукорененных интеллигентов, о том, что на пороге смерти отдельная жизнь выглядит прихотью случая и что он был на земле вовсе не необходим. «Слушай, - теперь признается он Жану, - не будь тебя здесь, мы бы страдали бессмысленно, как животные, не зная за что. Но ты с нами. И все, что теперь случится, обретает смысл. Мы будем бороться. Не за одного тебя, за всех товарищей... Если мне немного повезет, пожалуй, смогу сказать, что умираю не зря». «Бытие-к-жизни», «бытие-к-другим» оказывается гораздо подлиннее «бытия-к-смерти», последнее не подлинно уже по одному тому, что оно скорее небытие - принудительное или добровольное захоронение себя заживо.

Однако одно это еще не размыкает круга смерти, внутри которого идет нравственное сражение за жизнь. Действительное духовное содержание происходящего пока прояснено, по Сартру, далеко не до конца. Очередное обострение ситуации позволяет увидеть, что клубок куда запутаннее. В третьей картине обстановка на чердаке накаляется непереносимо. Между Жаном, которому в случае молчания остальных суждено жить, и его соратниками, которые отстаивают жизнь других, в том числе и его, но сами обречены умереть, разверзается пропасть отчуждения. В бездну рушится все, даже дружба, любовь, даже привязанность брата и сестры. Все, кроме заботы об общем деле, успех которого - залог того, что пытки перенесены не впустую, не напрасна и сама смерть. Сделать оправданными терзания тела, спасти свою поруганную душу, спасая товарищей, последнее, что осталось узникам. И ради этого они делают самый страшный шаг, руками Анри умертвив подростка Франсуа, который под пытками почти наверняка предаст. Умертвив не в припадке ожесточения или вражды, а обдуманно. Оттого что иного выхода нет и они подведены вплотную к той жуткой грани, когда на чаше весов одна жизнь - или шестьдесят, все прочее не в счет.

Можно сколько угодно укорять Сартра в бессердечии, неслыханном поругании заветов милосердия и выходе за пределы допустимого на подмостках — трудно не признать за ним права исследовать до конца самый крайний случай, коль скоро жизнь не так уж редко за- 


\section{Из архива}

гоняет в подобные тупики. Он же не спешит оправдать содеянное, полагая, что вынести окончательный приговор позволяет лишь полнейшая ясность относительно побуждений исполнителей. А как раз здесь пока все донельзя сложно. Зловещая магия пыток и смерти не оставила нетронутым сознание заключенных, внесла свою двусмыслицу. Выстоять во имя дела для пытаемых означало выйти победителем из очередной встречи с палачами. Встречи изнурительной до крайности, отбирающей все физические и нравственные силы без остатка. Постепенно непосредственная задача схватки двух воль оттесняла конечную цель, заслоняла, подменяла ее. Незаметно для себя жертвы замыкались исключительно в своем единоборстве с палачами. И вот уже почти забыты, отброшены все прочие, дальние соображения - идет голое состязание, смертельная игра, соперники жаждут выиграть - остальное не важно. Стенка на стенку. «Наплевать на их командира. Я хочу, чтобы они заговорили», - признается и главарь истязателей. Между жертвами и палачами возникает своя прочная связь-вражда. Люси, бывшая возлюбленная Жана, находящаяся среди пленных, отстраняясь от него, признается: «Я ненавижу их, но я в их руках. И они в моих тоже. Я чувствую себя ближе к ним, чем к тебе».

Что же, значит, смерть не мытьем, так катаньем заранее торжествует, независимо от исхода состязания? И те, кто полагают, что еще служат жизни, на самом деле уже обитатели загробного царства, окаменевшие, мертвые души? На алтарь какой же победы принесен труп мальчика, брата Люси? Не просто ли он козырь в чудовищной игре, чтобы побить последнюю ставку противников перед тем, как красиво умереть? Или мальчик все-таки задушен для спасения шестидесяти партизан?

Ответа нет, да его сейчас и не может быть - Сартр отказывается судить по намерениям. Дела - единственное, что может подтвердить или опровергнуть догадки, пролить окончательный свет на происшедшее. И для этой проверки крутой поворот действия снова возвращает троим уцелевшим свободу выбора внезапно распахивает запертую дверь в жизнь. После того как Жан вырвался на волю, пообещав подбросить свои документы к трупу одного из убитых накануне, легко направить преследователей по ложному следу. На последнем допросе шеф полицейских обещает всем помилование, если получит нужные показания. В их, и только в их власти теперь либо отказаться, тем самым признав, что они внутреннее накрепко скованы мнением палачей и отныне навсегда принадлежат смерти. Либо прикинуться дрогнувшими, пренебречь оценкой садистов, тем более что те обмануты, — и получить жизнь. Выбор должен придать тот или иной смысл убийству мальчика. От этого же зависит решение спора о скромности и гордыне, который вспыхнул еще в самом начале между Анри и Канорисом и затем, то разгораясь, то угасая, философски пронизал все перипетии трагедии.

Как и лишенный корней греческий принц Орест, французский студент-медик Анри угнетен сознанием своей призрачной невесомости, случайности, необязательности своего появления на свет и своего неизбежного исчезновения. Перед лицом сущего он не находит себе никаких «оправданий», он «излишен» - мог быть и мог не быть. Он заменим и сгинет, не оставив после себя никакой пустоты во вселенной, по-прежнему полной, словно свежее яйцо. Он и в партизаны пошел из тех же побуждений, по каким Орест решился мстить, чтобы добыть права гражданства среди себе подобных, избавиться среди партизан от гнетущего чувства своей невесомости, зряшности на земле. Провал, арест и скорая казнь, рассуждает с самим собой Анри, обнаружили тщетность этих надежд. Он как будто близок к тому, чтобы докопаться до самого существа людской участи, неутешительного, но существа. И им опять овладевает тревога за какую-то неведомую вину, непоправимую ошибку - то ли свою собственную, то ли мироздания, производящего миллионы разумных тростинок, не позаботившись сообщить им хоть мало-мальские резоны их сотворения.

По поводу всех этих бытийных терзаний товарища Канорис иронически замечает: уж не требуется ли неверующему Анри исповедник, чтобы даровать страждущему спасение души. «Ты оттого и страдаешь, добавляет он, - что нескромен», слишком носишься со своей персоной, ища ей особых оправданий если не Божественным промыслом, то какой-то его земной, но столь же священно-провиденциальной заменой. Сам Канорис куда скромнее. Его всегда мало волновала собственная личность, он жил для дела, слился с ним и считает себя мертвым с того момента, как перестал приносить пользу. Победа в том историческом сражении с фашизмом, в которое он вступил уже давно и вне которого не мыслил себя ни минуты, - вот с лихвой достаточное Канорису оправдание жизни и смерти. И ему не требуется дополнительных доводов ни от религии, ни от онтологии. В монолитной фигуре этого рядового солдата подполья, не знающего ни страха, ни сомнений, умудренного и закаленного годами, которые проведены им в гуще революционных битв, впервые под пером Сартра ожил, обрел свой душевный склад выходец из народной - остававшейся в «Мухах» безымянной - толпы. Один из тех, кому так иногда завидовал Орест, потому что они чуть ли не от рожде- 


\section{Филология: научные исследования 1 (09) • 2013}

ния постигли, с кем, против кого и зачем они на земле: путь их предначертан, когда-нибудь каждого ждет ответственный поступок, собственно его поступок - не заимствованный у других.

На первых порах, правда, разница между скромностью Канориса и гордыней Анри не имеет скольконибудь серьезного значения: когда смерть неминуема, не все ли равно, как именно ее встретить. Убийство Франсуа обостряет положение, но не настолько, чтобы вскрыть самый корень душевной раздвоенности Анри. Оно вносит добавочное смятение в его ум, он не вправе отвергнуть упрек Жана, что задушил из гордыни - не столько ради дела и товарищей, сколько ради себя: ради того, чтобы возможное предательство мальчика не лишило и его гибель обретенного было оправдания, ради возможности исправить допущенную на первом допросе слабость, выйти победителем из поединка с палачами и перед расстрелом взглянуть на них свысока. Он и сам не в силах разобрать, что именно возобладало в нем, когда он сжимал рукой хрупкое горло. А коль скоро это в конце концов опять-таки безразлично и Канорис, стой он ближе к мальчику, сделал бы то же самое, хотя его не упрекнешь в гордыне, то весь спор все еще беспредметен. Во всяком случае - не бог весть как важен.

Но вот, с появлением шанса остаться в живых, спор этот обретает небывалую ответственность. Анри жаждет смерти. Он выиграл партию, он может теперь умереть, примирившись с собой, гордо. Под пытками он еще раз убедился, что мир, производящий извергов, подобных их мучителям, - нелеп, постыл, омерзителен. И когда представляется случай покинуть его незапятнанным, слишком глупо этим не воспользоваться. Благо и успокоение в том, чтобы не растерять невзначай подлинность и величие духа, достигнутые на свидании со смертью, а ведь это не исключено, раз завтра опять придется столкнуться с житейскими ловушками. Не лучше ли громко хлопнуть дверью вовремя? Но тем самым первоначальный выбор обнажает свою подоплеку: гордыня поддерживает себя заботой о сугубо личном «спасении души» и готова пренебречь делом. Героизм здесь таит в себе боязнь оступиться на следующем шаге, свобода настолько не доверяет себе, что предпочитает венчающую ее гибель дальнейшему вторжению в жизнь, где ее ждут всяческие подвохи.

Свобода самодовлеющая, героизм отчаянных крайностей, гордыня - все это в «Мертвых без погребения», в отличие от «Мух», уже поставлено Сартром под сомнение. Несмотря на участие к излюбленному своему детищу, бытийно бесприютному вольнолюбцу, писатель на сей раз не идет на поводу личных склонностей.
И не отмахивается от иной точки зрения на вещи, раз уж она попала в поле его наблюдений и он, пусть пока только со стороны, признал ее законность и даже справедливость. Кряжистый грек гораздо более чужд Сартру, чей мятущийся интеллигент, и все же за Канорисом и настоящее мужество, и настоящая правда. Он старше, его усталость копилась годами, да и пытали его беспощаднее, чем остальных. Он вовсе не цепляется за жизнь, ему тоже легче с ней расстаться. Но он выбирает жизнь, потому что смерть поистине бесполезна, а от живого есть польза общему делу: «Незачем попусту швыряться тремя жизнями... Мы не имеем права умирать зря... Надо помочь товарищам... Надо работать. Спасение придет само собой... Если ты дашь себя убить, пока еще способен делать дело, не будет ничего нелепей твоей смерти». Довод за доводом - и в каждом не просто личная стойкость, но и зрелость мысли. Одно за другим побивает крепкий умом и духом старый подпольщик возражения собеседника, весьма поднаторевшего в хитросплетениях философствования. «Бытие-к-смерти» снова оказывается посрамленным, на сей раз в нравственной плоскости: гуманистическое «бытие-к-другим» выше, истиннее, достойнее. Оно требует от человека такой преданности долгу, такой душевной закалки и выдержки, такой мощи натуры и житейской мудрости, какие по силам личностям и в самом деле недюжинным, при всей их внешней заурядности. Скромный героизм служения труднее, но и неподдельнее героизма жестов, в первую очередь озабоченного личным душеспасением, как бы оно ни мыслилось — на христианский или обмирщенный лад.

Умозрительное поначалу, сопоставление этих двух установок к концу, в завершающем разговоре Канориса и Анри, прямо касается самого болезненного эпизода во всем, что случилось на школьном чердаке: ведь от последнего выбора зависит и до поры до времени отсроченный, подвешенный в воздухе, но необходимый ответ на мучительный вопрос - во имя чего же принесен был в жертву мальчик? Предпочти теперь Анри смерть, он собственноручно скрепит себе приговор: да, дело для него менее важно, чем он сам, да, он задушил не ради тех шестидесяти, а ради себя, чтобы не потерять надежды на достойный восхищения, торжествующий финал. И следовательно - ему нет человеческих оправданий. «Послушай, Анри, - высказывает Канорис последнее и едва ли не самое психологически веское соображение, - если ты умрешь сегодня, черта подведена: значит, ты убил из гордыни. Если же ты останешься жить... тогда ничего не потеряно: о каждом из твоих поступков будут судить по всей твоей жизни». Получается, что и личное-то «спасение» 


\section{Из архива}

по-настоящему тоже в скромности, в возврате вопреки всему в ряды сражающихся. Лишь работа на благо других может, согласно Канорису, послужить в какойто степени оправданием и смерти мальчика, и тех, кто решился на предупредительную казнь.

Но согласия Анри мало, последнее слово принадлежит Люси, а с ней все обстоит значительно сложнее. На ее женскую долю выпали испытания, не сравнимые даже с муками остальных. Во время пыток она изнасилована, с ее молчаливого согласия уничтожен любимый младший брат. К. тому же она натура скорее интуитивная, труднее поддающаяся уговорам, чем Анри, во всем отыскивающий логику и поступающий согласно рассудку. Потрясения предыдущего дня внушили ей такое отвращение к своему опозоренному телу и поруганной чести, настолько выжали, опустошили душу этой женщины, сначала как раз выделявшейся среди товарищей своей привязанностью к воспоминаниям о чистых и радостных минутах прошлого, что она теперь наглухо замурована в желании исчезнуть с лица земли. Она поставила крест на всем, кроме исступленной мечты унизить перед расстрелом насильников, заставив их признать торжество ее несломленного и потому оставшегося незапятнанным духа. Отныне никакие увещевания, никакие доводы на нее не действуют. И тут Сартр находит блистательный ход, как бы передоверив слово самой жизни. За окном падают редкие предгрозовые капли, и вдруг на землю обрушивается ливень - летний, щедрый, несущий свежесть, все омывающий и врачующий. Дождь развеивает кошмарные чары, поработившие изнемогший разум Люси, возвращает ей способность плакать и улыбаться, волю воскреснуть и жить наперекор страданию, наперекор манящему самозабвению в смерти. Стихийный порыв побуждает ее сказать робкое «да», стряхнуть оцепенение и заново родиться для надежды, омраченной, но всетаки надежды. И свидетельствует, что она и прежде не была безвозвратно по ту сторону от жизни, что пустыня небытия не поглотила ее сердца.

Прихоть одного из палачей, осмелившегося из природной подлости или зверского озорства ослушаться приказа начальства и перестрелять заключенных, обрывает это воскресение к жизни. Мертвецы остаются лежать на школьном дворе непогребенными. Но они погибли не просто великомучениками, они пали победителями. Они молчали под пытками и одержали верх в неравном поединке с истязателями. Они сделали больше - одолели жуткое наваждение, которое заживо хоронит обреченного умереть, отрывает от товарищей и близких, от всего на свете, и толкает на невольное отречение от того, что он считал своим призванием на земле. Служение правому делу они предпочли самозакланию.

«Мертвые без погребения» Сартра - пожалуй, единственная героическая трагедия французского театра XX в., действительно наследующая суровый пафос корнелевского долга: тут нет поругания гражданского исторического поприща как царства отчуждения личности, сплошь неподлинного, лицемерного, пропитанного отравой «ловчащей совести». Умонастроение «смыслоутраты», не лишаясь своей исходной пантрагедийности, находит смысл в освободительно-патриотическом служении и его утверждает. Сартр отнюдь не закрывает глаза на историю разрушительную, которая калечит души, делая обывателя скотом и палачом. И вместе с тем пробует нащупать к ней неоднозначный подход, уловить и нечто другое - то, что созидает, строит, выковывает настоящие души.

А потому он перестает заблуждаться и насчет метафизического повстанчества по наитию, запальчивых вызовов всем «другим» - ослепленной толпе и кровавой диктатуре одновременно, как это было в «Мухах». Своих партизан на свидании со смертью он заставляет перейти от ничего не желающего слушать «нет» к стократ труднейшему «да». «Да» вовсе не приспособленческому именно потому, что исторический поток отныне видится неодномерным, неодносоставным, разнонаправленным: в нем есть чему оказать поддержку и в чем ее для себя почерпнуть, придав осмысленность своей отдельной жизни, а быть может, и самой смерти. На бытийной чужбине, во вселенной вещей сартровскому носителю свободы по-прежнему некуда прислониться. Однако внутри этой пустой молчащей огромности вроде бы брезжит сгущение поплотнее, где тоже не вовсе спокойно, устойчиво, а существует ряд меняющихся возможностей. Но есть среди них и такая, которая обещает - коль скоро шаг выверен, - что не сорвешься в бездонный провал. В глазах Сартра времен «Мертвых без погребения» трудиться и приносить пользу на ниве исторического занятие достаточно скромное, порой мучительное и неблагодарное, зато в высшей степени достойное. Здесь очень и очень нелегко и непросто. Тут мало быть страстотерпцем и бунтарем, работники - куда пригоднее.

\section{4}

И все-таки, даже воздавая сполна должное тому запасу душевной прочности и мужества, какой приносит бытийно неприкаянным совет: «Надо работать. Спасение придет само собой», - тем не менее к концу «Мертвых без погребения» безотчетно-непосредственное нравственное чувство не может отделаться от 


\section{Филология: научные исследования 1 (09) • 2013}

подозрений, что в этом афоризме не все ладно, что-то тяготит, настораживает. Обдумав, нетрудно заметить, что душеспасительная озабоченность Сартром отнюдь не снята, а остаточно сохранена: «спасение» должно окольно «приложиться» к работе, быть наградой за нее и выглядит сокровенной целью личности, неизменно подразумеваемой. Во всяком случае, работник в истории снисходительно допускает право на подобный запрос, раз уж оно так нужно спасающемуся в истории интеллигенту. А стало быть, в свете убийства мальчика ради нужд дела, пусть не своекорыстного, - русская память почти наверняка предположит здесь отзвук рассуждений у Достоевского о слезинке ребеночка, пролитой во имя грядущей всемирной гармонии, заповедь старого партизана с ее отпущением грехов прочитывается не больше не меньше, как разрешение на «кровь по совести», если прибегнуть к словами того же Достоевского.

Что для Сартра это именно так, подтвердило, в частности, вынесенное в заголовок его очередной пьесы и вызывающе перетолкованное им словосочетание «грязные руки». «Грязные руки» - это звучит здесь не как хула, укор в чем-то отталкивающе-нечистоплотном, стыдном. Наоборот, грязные руки тут противопоставлены, с одной стороны, рукам белоручек-чистоплюев, брезгающих браться за полезную черную работу в текущей истории из боязни замараться. Ас другой впечатляюще окровавленным рукам вольных или невольных «факиров свободы», вроде Ореста из «Мух», надеющихся, будто кошмарное причастие позволит им сделаться своими среди облагодетельствованных, а вернее, обольщенных ими сограждан. Признак скромности, а не гордыни, испачканные руки, по Сартру, - достояние рядовых тружеников политики, «ассенизаторов и водовозов» истории. Тех, кто без смущения выполняет свое нужное дело, уповая, что «спасение придет само собой». Или, выражаясь проще: что все или почти все зачтется и спишется самим успехом предпринятого с благими намерениями. И чтобы мудреное на слух выворачивание наизнанку привычных слов не ускользнуло от зрителя, Сартр вложил свое пояснение к ним в уста бывалого революционераподпольщика, который растолковывает очередному преемнику гордеца Ореста: «Как ты дорожишь своей чистотой, малыш. Как ты боишься запачкать руки. Ну и оставайся чистым! Чему только это послужит и зачем ты пришел к нам? Чистота - это идея факиров и монахов. Вы же, буржуазные анархисты, вы превращаете ее в предлог, чтобы ничего не делать. Ничего не делать, оставаться недвижимыми, скрестить руки на груди, натянуть перчатки. У меня же руки в грязи. Я их по локоть погрузил в дерьмо и кровь. И дальше что?
Не думаешь ли ты, что возможно управлять людьми, соблюдая невинность?» ${ }^{4}$.

Позже Сартр подтвердил уже от себя, что находит позицию своего ревнителя «грязных рук» предпочтительной и «здоровой» ${ }^{5}$.

И тем довольно бестрепетно приблизился вплотную к заключению, что действию внутри истории нравственная чистоплотность в общем-то обуза, ничто не запрещено и все позволено, лишь бы ставилась справедливая задача. Там, где Мальро когда-то в «Надежде» в раздумье заколебался и повернул назад, к квазирелигиозному спасению в культуре, там Сартр - быть может, с нелегким сердцем - подавляет растерянность и устремляется до конца по избранной стезе. Внутри собственного философского ряда он совершенно последователен: если крушение «священной санкции» сметает веру в какие бы то ни было сущности, по которым можно выверять и оценивать поступки, то нравственных принципов нет, а есть одни изменчивые обстоятельства. И на историю это должно простираться в первую очередь. Хладнокровная арифметика — вот и все предлагаемое правило: один меньше двух, следовательно, при деловой необходимости им пожертвовать, его заклание «по совести разрешено».

Мировоззренческое «добро», которое Сартр дает подобному делячеству от истории, весьма метко было окрещено как «историцизм». Театральным манифестом последнего явилась пьеса «Дьявол и Господь Бог» (1951).

...Рыцари-наемники и лесные отшельники. Мятежное городское простонародье, погрязшее в суевериях крестьянство. Откупщики и шлюхи в походном обозе. Церковники всех мастей и рангов - сановники в сутанах, бродячие монахи, пастыри бедноты, самозваные пророки. Развороченная Крестьянской войной Германия XVI столетия, где распрям и междоусобице нет конца, где все ополчилось на всех: города на архиепископов, крестьяне на сеньоров, владельцы замков - на соседей, брат - на брата. А исчадие этой войны, Гёц фон Берлихинген, помимо всего прочего, еще и на Отца небесного - самого Господа Бога.

И все же сартровский «Дьявол и Господь Бог» не хочет даже прикинуться пьесой исторической. Прошлое не реставрируется, просто-напросто в его гардеробе берутся напрокат костюмы. Трезвые доводы и кощунственные хулы, обрушенные с подмостков в зал, звучат откровенным анахронизмом: то перекличкой с Тертуллианом, Паскалем и Достоевским, то глухими отголосками Кампанеллы, Толстого и Ганди, что-то

\footnotetext{
${ }^{4}$ Sartre Jean-Paul. Theatre. P. 304.

5 См.: Jeanson Fr. Sartre par lui-meme. P., 1955. P. 48.
} 


\section{Из архива}

отдаленно намекает на марксизм, вот это уж прямо из Ницше: «Бог умер». Одного только недостает в этом интеллектуальном Вавилоне: схоластического богословия и реформаторских ересей, Лютера и Мюнцера умственного крошева самой тогдашней Германии. Да и у самого Гёца нет его знаменитой «железной руки» кажется, одного из первых протезов в истории. «Дьявол и Господь Бог» - не эпизод из феодальных смут и народных бунтов Позднего Средневековья, а притча обинтеллигенте - «богоотступнике» и «смыслоискателе». Очередной театрализованный миф трагического гуманизма XX в.

Едва ли не самая «барочная» из пьес Сартра, смахивающая на старинные мистериальные действа, взвинченная, вся в перепадах от святотатственных корч к молитвенной елейности, — «Дьявол и Господь Бог» в самой своей стилистике несет отпечаток мировоззренческой ломки, нелегко давшейся переходности. Словно собрав ведущие нити своей предшествующей умственной работы в единый пучок, писатель пробует оборвать их разом, за исключением одной - той, держась за которую он намеревается двигаться дальше. Поэтому здание этой философской «мистерии» - в отличие от прежних математически рассчитанных построек Сартра-драматурга - с трудом выдерживает перегрузку идей, грозя вот-вот развалиться. Отсюда рыхлая громоздкость этой более чем четырехчасовой театральной махины, куда ее изобретатель, опасаясь упустить оттенки, усиливается втиснуть накопленное и передуманное за многие годы. Отсюда - словесная невоздержанность Гёца и его собеседников: обсуждение на подмостках, дорожа каждым сколько-нибудь приметным изгибом, вьется и петляет, возвращается вспять, топчется на месте, пока не исчерпает себя до конца. Отсюда - нестрогость, разнобой, гротескная разномастность текста, где мелодрама соседствует с шаржем, почти клоунадой, теологический диспут подкрепляется игрой в кости, где утопическая пастораль пародийна, а жутковатое фиглярство вознесено истерикой до уровня откровений. Сартр, раньше старавшийся обычно замкнуть действие чуть ли не в четырех стенах, при этом взяв его сразу в наивысшей точке, совсем близко к развязке, теперь растягивает его на год, переносит из походной палатки в церковь, из замка в лес, из кабинета на площадь и в лачугу. Одного диалога, когда стороны звено к звену выравнивают цепочки своих доводов, ему уже недостаточно: сшибка «правд» по-прежнему дает философский стержень происходящему, но заблуждения побиваются не столько выкладками ума, сколько наглядными уроками-зрелищами; изощренная логика подтверждается или опровергается чредой событий им предоставлено вершить последний суд.
Когда-то у Сартра еще Орест возвестил первым «сумерки богов». Сумерки, однако, затянулись, коль скоро лихому вояке Гёцу, дух которого вовсе не истончен изысками скептического воспитания, пришлось сызнова начать все хождения по мукам, записываться в яростные мятежники против Всевышнего, прежде чем провозгласить пришествие царства человека.

И дело здесь в самой природе того богоборчества, того бунтарски-отрицательного полагания веры и подыскивания взамен ей мирских душеспасительных святынь, к какому Сартр неосознанно склонялся с самого детства. В автобиографической повести «Слова» (1961) есть по этому поводу чрезвычайно примечательное признание. К концу этого рассказа о детстве Сартр очерчивает скрыто-религиозную подоплеку своей ранней страсти к писательству: «Сквозь устарелую концепцию культуры просвечивала религия, она служила образчиком... В процесс ее горообразования произошло смещение коры: идея святости, позаимствованная у католицизма, была вложена в изящную словесность, я не сумел стать верующим, поэтому увидел эрзац христианина в литераторе: делом его жизни было искупление, пребывание в земной юдоли имело одну цель - достойно пройти через испытания и заслужить посмертное блаженство... На меня воздействовала огромная коллективная сила - то была вера других; угнездившись в моем сердце, она ждала своей минуты: стоило переименовать предмет ее поклонения и слегка изменить его облик, как она, узнав его под маской, которая меня ввела в заблуждение, кинулась, вцепилась в него когтями. Я думал, что отдаюсь литературе, а на самом деле принял постриг... Я рос сорняком на унавоженной почве католицизма, мои корни впитывали ее соки, наливались ими... Остался другой, незримый, святой дух, гарантировавший выданные мне полномочия и правивший моей жизнью с помощью безымянных, великих священных сил. От него было тем трудней избавиться, что он обосновался в тылах моего мозга, среди тех полученных из-под полы терминов, которыми я пользовался, чтобы понять себя, свое место в жизни, смысл своего существования. Я предался церкви. Воинствующий ее адепт, я искал спасения в творчестве; мистик, я пытался вторгнуться в молчание бытия раздражающим шорохом слов» ${ }^{6}$.

Для такой - превращенно-реликтовой - веры ряд завоеваний атеистической культуры несомненен и необратим. Научно-рационалистическое, натурфилософское, просветительское опровержение религии усвоено подобным неверием как нечто само собой

${ }^{6}$ Сартр Ж.-П. Слова. М., 1964. С. 170-171. 


\section{Филология: научные исследования 1 (09) • 2013}

разумеющееся. Общественный вред церкви тоже не секрет, и в «Дьяволе и Господе Боге» Сартр язвительно и метко разоблачит ее всегдашнее правило принимать сторону толстосумов и прочих властей предержащих, политиканство ее вельмож, шарлатанские проделки монахов, наживающихся на темноте простого люда. Сартр знает, однако, по себе, что всего этого недостаточно, что «атеизм - предприятие жестокое и требующее выдержки» («Слова»). У довольствующегося лишь «прополкой вершков» сплошь и рядом не тронуты корешки - душевно не преодолен вероисповедный запрос, умеющий принимать множество самых неожиданных личин. «Дьявол и Господь Бог» и задуман как корчевка, так сказать, посмертного инобытия веры в складках подсознания - почивший на небесах Бог должен быть вырван из самого сердца и ума. Задача, при выполнении которой приходится иногда извлекать и выдергивать самые причудливые пережиточные верообразования.

Парадоксы тут неизбежны, и «Дьявол и Господь Бог» открывается как раз одним из самых ошеломляющих. Гёц поначалу вовсе не святоша, а напротив заядлый богохульник. Бога предстоит, следовательно, изничтожить в душе иконоборца, который только и помышляет о том, чтобы припереть к стенке небесного Отца. Уж кто, кажется, дальше от богопочитания, чем состоящий на жалованье у одного из князей Гёц — глумливый сквернослов, распутник, полководец - бандит с большой дороги, клятвопреступник и в довершение всего почти братоубийца. В глазах Сартра, однако, сей «бич Божий» не слишком далеко ушел от благолепной веры. Он просто-напросто вывернул наизнанку все христианские заповеди, «не прелюбодействуй» заменил на «греши напропалую», «не сотвори себе кумира» - на «возведи себя в сан богоравного», «не убий» - на «бесчинствуй», «не поминай всуе» - на «богохульствуй»... В принципе же он остался таким же моральным догматиком, как и самый истый верующий. Религия тщится вывести некие вечные, неколебимые, высеченные на скрижалях заветы, предложить раз и навсегда неизменные рецепты поведения в изменчивых обстоятельствах. И «завет наоборот» - все та же догма, та же несвобода, преклоним ли мы колена перед Спасителем или Сатаной. Гёц, присвоив себе звание дьявола во плоти, не перестал быть рабом Всевышнего хотя бы по той простой причине, что взор его прикован к небесам, а не к земле, что он внутри, а не вне магнитного поля верооткровенной нравственности. Поэтому даже смятенному попу-расстриге Генриху, разрывающемуся между церковью, прислуживающей владыкам земным, и своей нищей паствой, - ничего не стоит сбить Гёца столку, заметив, что злодеяния «фанфарона порока» на свой вывихнутый лад есть служба небесному хозяину, устроившему вселенную так, чтобы земля была юдолью несправедливости и смердела своими гнойниками до самых звезд. Гёц одна из овец послушного стада Господнего, только обрядившаяся в волчью шкуру.

Отсюда - предельная озлобленность, надрыв в богохульстве Гёца: самого себя оно сокрушенно переживает как отпадение от блаженства и изнутри насквозь расщеплено, несчастно. Ноша бунта для этих, как выясняется, хлипких плеч почти непосильна, поскольку Гёц так и не научился толком ходить по земле самостоятельно, без костылей священного, думать без божественных координат. У него все та же отправная точка отсчета, только со знаком минус: вместо Творца, обожаемого тварью, — Творец, ей ненавистный. А это влечет за собой выворачивание наизнанку и всех прочих одежек мысли. На место запрета попадает своеволие, на место пребывания в благодати - изгойство, на место Провидения произвол случая. Но, все так же завороженный небесами, ум по-прежнему находит свою пищу в первую очередь там, только испытывает перед ней не благоговение, а ярость.

Впрочем, в «Дьяволе и Господе Боге» Сартр не довольствуется указанием лишь на самообман такого изживания веры в вере же, но шиворот-навыворот. Гёц исступленный идолопоклонник Зла - Зла абсолютного и потому непременно с большой буквы, - не просто жертва рокового заблуждения, слепоты. Раньше Сартр, пожалуй, поставил бы точку, изрядно пощипав гордыню Гёца и доказав, как дважды два, логическую несообразность умозаключений подобного богоборчества - скорее антитеизма, чем атеизма. Теперь низвергателю, возомнившему о себе невесть что, уготовано и гораздо большее унижение: его просто тычут носом, как щенка, в те пакости, которыми оборачивается сатанинское повстанчество богомерзкого «трутня Господня». И сделает это просто булочник Насти: «Ты сеешь беспорядок, а беспорядок лучший слуга установленного порядка... Ты служишь... великим мира сего, Гёц, и всегда будешь служить. Бедные становятся беднее, богатые - богаче, а могущественные еще более могущественными». Сколько бы потом Гёц ни разглагольствовал, что он, мол, не чета прочим смертным, угроза всему Божьему устроению, а не червь земляной, что ему смешна муравьиная суета людишек, что, погубив тысячи жителей взятого города, он вроде бы распнет снова на кресте их надмирного заступника, сколько бы Гёц ни выворачивался с помощью словесных выкрутасов на тему «есть Бог и я, антихрист, все прочие - тени», — все равно ему не 


\section{Из архива}

стереть клейма, которым отметил его здравомыслящий вождь восставших горожан: «княжеский холуй».

Не часто получал столь звонкие и обидные оплеухи горделивый снобистский максимализм - то самое безудержно-анархическое бунтарство, что в особенности с конца XIX в. кружило головы множеству левых интеллигентов Запада, толкая отмахнуться от революционного преобразования жизни (по их понятиям: «возни вокруг смены министерств») и предназначить себе по-иному возвышенную миссию - мятеж никак не меньше, как против самого «творения». Культ всесветного переворота и вызова мирозданию был, скажем, духовным багажом и приверженцев «дада», и сюрреалистов, и экспрессионистов, и единомышленников раннего Сартра по абсурдистской «смыслоутрате». И чтобы здесь никаких сомнений не оставалось, сам Сартр в «Дьяволе и Господе Боге» позаботился уточнить свою мишень. Он поручил проницательному цинику-банкиру скрепить приговор Насти, перевести на привычные понятия XX в. и растолковать не проходившему университетов Гёцу: «Видите ли, я разделяю людей на три категории: те, у кого много денег; те, у кого совсем нет денег, и те, у кого денег немного. Первые хотят сохранить то, что у них есть, - их корысть в том, чтоб поддерживать порядок. Вторые хотят взять то, чего у них нет, - их корысть в том, чтоб уничтожить нынешний порядок и установить другой, который им будет выгоден. И те и другие реалисты... Третьи хотят уничтожить порядок, чтобы взять то, чего у них нет, и в то же время сохранить его, чтобы у них не отобрали то, что у них есть. Это значит, что они на деле сохраняют то, что уничтожают в идее. Это и есть идеалисты». Право, можно подумать, что старый пройдоха, объясняющий азы политграмоты «идеалисту» Гёцу, сам освоил их в школе по-простецки прямолинейного Брехта, не упускавшего случая вывести на чистую воду интеллектуала, захлебнувшегося в бунтовщических словесах.

Правда, Сартр берется за дело по-иному, чем Брехт: перед ним на анатомическом столе собственное недавнее прошлое - провозвестник «сумерек богов» Орест и его потомки. И каждую клеточку пораженной бытийной болезнью ткани он ощущает прежде всего изнутри, а прикасаясь хирургическим ножом к очагам воспаления, сам испытывает острейшую боль и оттого вскрывает их в какой-то остервенелой спешке. Гёц, как и его тень Генрих, норовит обозначать себя словечком покрепче, приличествующим в устах рубаки или расстриги: batard, что значит незаконнорожденный, помесь, ублюдок. Гёц - плод греха своей матушки - дворянки, сошедшейся с мужиком. Полубедняк-полусвященник Генрих тоже «ублюдок»: что- бы он явился на свет, «поп переспал с нищенкой». Но дело не просто в происхождении. «Ублюдочность»их общая доля, их социальное проклятие. Корни их там и здесь, там и здесь они чужие, их связь с родной почвой ослаблена. Отщепенцы по натуре, судьбе и устремлениям, они не внутри жизни, а словно бы вне, поверх нее. И чувствуют себя везде «излишними», исключенными отовсюду.

А это дает мучительную душевно-мировоззренческую закомплексованность. Гёц, как и Орест до него, перекати-поле и тоже одержим желанием где-то закрепиться, утвердиться в жизни, стать значимым, полновесно присутствовать. Сделать это он может, лишь поминутно напоминая и себе, и всем остальным, что он есть, что он не мираж, не призрак, не тень. Самому себе он доказывает это, без конца возвеличиваясь в собственном воображении, избирая самого исполинского соперника - Бога, коли уж нельзя грознее, представая перед собой в ореоле легенды - Сатаной, Люцифером, потом чуть ли не Христом. Так возникает искус абсолютного - будь то чистейшее Зло или столь же чистое Добро.

С другой стороны, он ненасытен в желании быть всегда на виду, в окружении зрителей: в их глазах он ищет свой облик, будучи не уверен без этого в определенности своего существования. Подобно «завоевателям» Мальро и подобно Оресту, он навечно актер, лицедей, превращающий вселенную в подмостки и зрительный зал своего личного спектакля. Вселенная же, в свою очередь, платит ему сторицей за попытку обратить ее в театр, где жизнь подменена иллюзией жизни. $\mathrm{Bce}$, что он проделывает, оказывается не поступком, а иллюзией поступка, не делом, а жестом. Замечая это, он торопится поправить положение, снова и снова меняя маску. И попадает в капкан своего же прирожденного предательства - на каждом шагу изменяет и себе, и остальным. «Конечно, ублюдки предают, - выворачивает свою душу Гёц, — что они, по-твоему, могут еще делать».

Капкан подстерегает Гёца и тогда, когда он, убедившись, что Бога не достанешь и не заденешь нагнетанием злодейств, пробует соперничать с ним милосердными благодеяниями. Из «совершенно чистого изверга» он преображается в блаженнейшего святого. Крестьяне враждебно встречают несусветную доброту своего впавшего в юродство помещика, которому втемяшилось в голову раздать все земли. Он им не ровня, он их презирает и дает им, чтобы презирать еще больше. Гордыня, а не скромность движет им. И еще - желание въехать в рай на чужой спине. Сметка, завещанная поколениями предков, подсказывает крестьянам, что все это Добро - ко- 


\section{Филология: научные исследования 1 (09) • 2013}

нечно, тоже непременно с большой буквы - до добра не доведет. И тогда Гёц, еще недавно разгонявший шарлатанов-торговцев индульгенциями, совершает самый мелодраматический и самый шарлатанский из своих жестов: наносит себе раны кинжалом, мажет кровью распятие и увенчивает себя титулом Христова посланца на земле. Поначалу, правда, как и все у Гёца, это искренний порыв пострадать на глазах у бывшей солдатской шлюхи, чтобы искупить вину за то, что он когда-то ее соблазнил и сделал своей походной подстилкой. Но уже в следующий момент порыв оборачивается двойным предательством: богохульник рядится Божьим помазанником, насилует разум своих подданных, спекулируя на их суевериях.

Вскоре и обманщик и обманутые на собственной шкуре испытают, чем чреват этот разыгранный перед алтарем кощунственный миракль. Лучезарный «город Солнца», в построение коего их вовлекает сумасбродный замаливатель своих грехов, оборачивается казармой безмозглых холопов. Колония принудительного «евангельского» братства, организованная им, - это попытка объегорить историю. Пусть вокруг вся страна охвачена военным пожаром. Гёц твердит: «Не убий!». А ему вторит, словно стая попугаев, его духовно кастрированная паства. На деле же его не заботит судьба обитателей утопического града. Ему наплевать на их будущее, ему там не жить, он хочет причаститься благодати сегодня, сейчас, здесь. Спасение души Гёца, теперь уже в самом что ни на есть прямом христианском смысле, да еще за счет оболваненных им непротивленцев, - вот истинная суть всей затеи. Снова погоня за абсолютом обнаруживает свою изнанку - самоспасение корыстнейшего свойства, возведенное в абсолют шкурничество. Нет, не мелкое, пошлое, житейское, а, так сказать, по бытийном счету - и оттого особенно опасное. «Город Солнца», сделавшийся бельмом в глазу для всей бедствующей Германии, ожидает участь всех подобных предприятий: он стерт с лица земли вместе с обитателями.

И вот в лесу перед Генрихом, пришедшим подвести итог их старому спору о добре и зле, Гёц договаривает все до конца. Да, он с самого рождения лгал, лгал порой бессознательно и нередко вполне осознанно, лгал апостолом Зла и лгал апостолом Добра. Да, он помышлял только о себе, когда истязал окружающих обидами и еще пуще истязал благодеяниями. Да, он никогда не менялся, менялись только его амплуа. Да, он всегда оставался «ублюдком» и предателем, всегда подменял дела жестами, всегда фиглярствовал.

Значит ли это, что капкан захлопнулся, что отщепенец обречен веки вечные болтаться в предательской пустоте и до самой смерти не отделаться от самочув- ствия «ублюдка»? Или Гёцу объявлен все-таки не мат, а только грозный шах?

Перед последней встречей с Генрихом Гёцотшельник, укрывшийся от мирских мытарств в лесу, волею Сартра возвращается после всех нагромождений лжи к простому и голому, как сама очевидность, умозаключению. Пока Бог есть, человек ничто, комок грязи, и его позволительно стереть в порошок. Чем и занимается Гёц, сперва ради своего вызова «Творцу» измываясь над окружающими «тварями Господними», а потом истязая и свою плоть, смиряя свой дух, разрушая себя. Нравственность, покоящаяся на верооткровении - даже если она рядится безбожием и всесветным мятежом, сохраняя при этом изначальный догматизм, - во всех случаях, по Сартру, есть уничтожение, перечеркивание личности.

Но умозаключение Гёца ведь нетрудно и перевернуть: если человек есть, если он мыслит и живет, если он свободен - значит, небеса пусты, Бог - ничто, его нет, а есть один обман и самообман. Умозаключение даже должно перевернуть, окинув взором то, что у тебя позади, и со всей четкостью признав, что на трудных жизненных распутьях, когда ты молил Всевышнего о совете помощи, он всегда молчал, а ты сам, по своей доброй или злой - воле, подстраивал знамения свыше, плутуя. «Генрих, — кричит прозревший наконец Гёц, — ты сейчас узнаешь от меня о самом большом жульничестве: Бога нет... Бога не существует... Нет небес, нет ада! Есть лишь одна земля... Прощайте, изверги! Прощайте, святые! Прощай, гордыня! Нет ничего, кроме людей». Есть вроде бы выход из мышеловки, жизнь можно попробовать переиграть, начать сызнова? Простившись с Богом, заклав его в себе. Расставшись с подогреваемыми им метафизически-абсолютными притязаниями. Покончив с «ублюдком» перекати-полем.

Сартр казнит своего Гёца беспощадно, но это не смертная казнь. Гёц подлежит возврату к жизни. И первый шаг здесь - оторвать взор от молчащих небес, опуститься на просто землю с ее просто обитателями, а не «тварями Господними» - не ангелами и не чертями. Но этого мало - в жизни действительной каждый себя выбирает, хочет он того или нет, определяясь относительно сталкивающихся в истории лагерей. Гёцу предстоит сделаться не голым человеком на голой земле, а человеком среди людей. Каким должен быть этот второй шаг, ему уже давно подсказывает Насти пожалуй, самая двусмысленная фигура «Дьявола и Господа Бога».

Пророк бедноты, Насти - человек совсем иной породы и закваски, чем Гёц. Гёц — «ублюдок» без прочных корней, Насти - плоть от плоти и кровь от крови 


\section{Из архива}

своих братьев по нищете, по оружию. Гёц озабочен личным душеспасением и тешит себя броскими жестами, Насти весь в деле, с которым навек сросся. Гёц воюет с Богом - Насти с головой погружен в историю. Гёц все мыслит в застывших вечных категориях — мышлению Насти догматизм чужд, нравственность он черпает не в заповедях, а в насущных нуждах. Сама жизнь научила его, что, скажем, «не убий» в разгар гражданской войны граничит с дезертирством и преступлением перед своими, а простодушная честность - наихудшее оружие против вероломного врага. Непорочность в его глазах самообольщение чистюль, норовящих перехитрить, объехать по кривой свой век. Он же знает, что от жизни с ее кровью, грязью, гноем никуда не деться, что с сегодня на завтра белоснежными небожителями не становятся и надо, не боясь замарать руки, постараться сделать жизнь чуть-чуть почище.

Умом Сартр на стороне Насти, в конце концов к нему приводит он и своего Гёца. И Гёц под занавес с особой четкостью выскажет ту конечную правду, которую Насти уже давно нес сквозь события пьесы и которая становится нравственно-философской почвой союза между крестьянами-повстанцами и рыцаремполководцем: «Люди нынче рождаются преступниками. Я должен взять на себя часть их преступлений, если хочу завоевать хоть часть их любви. Я возжелал чистой любви. Глупец! Любить - значит вместе с другими ненавидеть общего врага. Я разделяю вашу ненависть. Я возжелал Добра. Глупец! На земле теперь Добро и Зло неразделимы. Согласен быть злым, чтобы стать добрым». Такова суть морали недогматичной, относительной, приспособленной к истории — и потому, убеждает себя Сартр, единственно действенной, созидательной, призванной заменить мораль абсолютную - и потому лицедейскую, разрушительную. «Контраст между уходом Ореста в конце «Мух», - свидетельствует в своих воспоминаниях спутница жизни Сартра, Симона де Бовуар, — и присоединением Гёца к крестьянскому войску указывает на расстояние, пройденное Сартром от анархической позиции к ответственной включености в историю, к «завербованности» ${ }^{7}$.

Однако принять разумом еще не значит сразу же согласиться и душой. Крепко стоящий обеими ногами на земле Насти притягивает к себе Сартра — и одновременно настораживает, поскольку для него не секрет изнанка морали, жертвующей всем на свете делу и полагающей совершенно подвижными, если не вовсе несущественными границы между добром и злом. Еще в «Грязных руках», предвещая беседу Насти и Гёца, происходил следующий разговор:

\footnotetext{
7 Beauvoir Simone de. La Force des choses. P., 1963. P. 261.
}

«-Когда надо, я буду лгать товарищам... Не я придумал ложь, она родилась вместе с обществом, расколотым на классы, и каждый из нас унаследовал ее при рождении. Мы упраздним ложь не тогда, когда откажемся лгать, а тогда, когда пустим в ход все способы, чтобы уничтожить классы.

- Не все способы хороши.

- Все способы хороши, если они действенны».

В «Дьяволе и Господе Боге» Насти не просто возникает время от времени перед Гёцом как перст указующий. Позади у него тоже своя история, и трагическая. Однажды допустив, что провозвестнику грядущего райского сада на земле все простится, что он волен, не сообразуясь ни с каким нравственным законом, кроме выгоды для дела, быть неразборчивым в средствах, только бы они обеспечивали успех, Насти идет навстречу душевному краху. Сперва демагогия, провокация - надо выиграть день-другой, потом умолчание - правда слишком угрожающа, затем ложь во спасение - все стремительнее это соскальзывание по наклонной плоскости. Ширится пропасть между Насти и товарищами, и вот уже он не равный среди равных, а вождь, вознесенный над остальными и скрывающий от них свои замыслы. Он обращается с ними как с быдлом, стадом баранов, слепым капризам которых иногда приходится потакать, чтобы удержаться во главе, а еще чаще - туманить мозги, чтобы они послушнее шли на убой. Ревнитель народовластия мало-помалу перерождается в плебейского Макиавелли.

Неудивительно, что, несмотря на твердую окончательность, отсутствие и тени сомнений в речах новообращенного крестьянского полководца Гёца, щемящая тоска обволакивает последние сцены «Дьявола и Господа Бога». Мысль самого Сартра мечется, догадываясь, что Гёц после стольких мытарств и смен кожи вернулся в некотором роде все к тому же разбитому корыту — чувству роковой «бездомности». И на земле он до конца своих дней пребудет перекати-полем. В кровавом причастии он побратался с повстанцами - и все же не стал их братом. Он возвестил «царствие человека на земле», заколов человека, подчиненного ему, сделавшись «палачом и мясником». Вступив в поток истории, он выяснил, что здесь еще более одинок, чем на поединке с Богом. И последнее открытие: отчужденность - вовсе не его привилегия, Насти, оказывается, тоже бесконечно одинок. Значит, одиночество, неукорененность в гуще людской - это и есть неизбывный жребий личности, ее каинова печать? Революция, позволяя шагать в ногу с другими, многими, по Сартру, не только не приглушает, но и подчеркивает извечную бесприют- 


\section{Филология: научные исследования 1 (09) • 2013}

ность человека во вселенной. Все живут, трудятся, сражаются и умирают с ледяным холодом взаимной отчужденности в душе.

Но как бы то ни было: «или - или» стягивает Сартр к концу ветвящиеся мотивы театральной мистерии об «ублюдке-военспеце» Гёце фон Берлихингене. Чистоплюйство - или грязные руки, культ жеста или культ дела, нравственный максимализм - или нравственный нигилизм, абсолют догмы - или полная относительность. Одна позиция обрекает на бесполезное сотрясение воздуха, а то и на пособничество несправедливым порядкам, другая чревата вседозволенностью. И поскольку, по Сартру, третьего историей как в далеком прошлом, так и в XX в. - не дано, а всю никчемность сражения с ветряными мельницами он уже изведал сполна, он предпочитает, зажмурив глаза и с каким-то ожесточением расчесывая язвы совести, толкнуть своего Гёца в противоположную крайность. Мол, была не была: лес рубят — щепки летят. После разберемся.

Лобовая сартровская дилемма, как ни крути, таит в себе опасность такого «лесозаготовительного» подхода. «Ты принесешь в жертву двадцать тысяч крестьян, чтобы спасти сто тысяч», - подает Насти совет Гёцу, приглашая его командовать повстанческим войском, где дисциплину предстоит налаживать с помощью обмана и казней («для острастки»). Арифметики от истории XX в. в сходных случаях ведут счет покрупнее - на миллионы, а то и на сотни миллионов. Да только загубленные человеческие души и жизни - не палочки и крестики в расходно-приходной книге истории. «Есть Бог, я и прочие, пешки», - полагал Гёцмаксималист; есть дело, начальник и прочие, пешки, прозрел вслед за Настей Гёц-релятивист. Полюса, выходит, гораздо ближе друг к другу, чем можно было подумать поначалу.

Да так оно и есть на самом деле: и лицедейство в истории, и «историцистское» счетоводчество одинаково чужды подлинно историческому творчеству, стоящему на том, что рождение свободной и полноценной личности должно начинаться с прихода человека в революцию. И последней уже по одной этой причине следует остерегаться малейшей нечистоплотности, лжи, безнравственности, рискуя в противном случае взрастить не борцов и созидателей, а деляг, способных угробить само дело, за которое взялись. Раздумья Сартра вовсе не праздны. Напротив, они касаются вещей чрезвычайно острых, болезненных. Ведь оправдание моральной невзыскательности исторической пользой, в прошлом столетии сбившее с толку немало пылких голов, подтолкнув их, по слову Маркса, к «казарменному коммунизму» и революционаристской уголов- щине, в XX в., случается, оплотняет грезы до яви. «Историцизм» имеет подчас хождение в масштабах огромных государств, где «культурные революции» оборачиваются и против культуры, и против революции, и против людей. И где кое-кто из строителей «солнечного града» не прочь хладнокровно прикидывать в уме, сколькими миллионами жизней и какими пространствами выжженной земли позволительно пожертвовать ради «блаженства» тех, кому суждено уцелеть, если таковые вообще будут.

Однако при всем своем аналитическом даре Сартр затрудняется помочь своим выломившимся из мирового бытия детищам, когда они терзаются проклятым «или - или». Он дает понять, будто приобщил своего Гёца к революционной нравственности, но ведь Насти всего-навсего склонил его к псевдореволюционной, иезуитской безнравственности ${ }^{8}$.

Издержки и ущерб от нее, кстати говоря, обычно с лихвой перекрывают столь чаемую выгоду. Помимо невольно внушаемой неприязни к делу, которое берется обеспечить эта всеядность, помимо не раз случавшегося в истории и прослеженного Сартром перерождения исповедующих ее освободителей в худших закрепостителей, она, сама того не замечая, оказывает этому делу еще одну крайне сомнительную услугу. А именно: подрывает на корню и самые основы выбора в его пользу. «Всякая Мораль, которая не полагает себя невозможной сегодня, - философски благословлял подобную ценностно-поведенческую неразборчивость Сартр год спустя после «Дьявола и Господа Бога», - способствует мистификации и отчуждению людей. Моральная «проблема» порождена тем, что Мораль для нас одновременно и неизбежна и невозможна» ${ }^{9}$. Действию предлагается извлечь свои этические установки из этой неустранимой невозможности и в свете ее решать для себя вопрос о праве на насилие, о соотнесенности цели и средств. Но если, оставив в стороне игру в слова, действительно смириться с этой невозможностью, быть хладнокровно последовательным и не пробовать идти ей наперекор, то как и почему тогда вообще возможно предпочесть одно дело другому, различить их сравнительную ценность и признать справедливым один выбор и несправедливым другой? Гёц принял правду повстанцев, но - при столь двусмысленной миросозерцательной посылке, согласно которой нравственное суждение

\footnotetext{
8 Спустя двадцать с лишним лет сам Сартр совершенно верно определил свою радикальную «замену абсолюта историей» как «реалистический имморализм» (Gavi Ph., Sartre J.-P., Victor P. On a raisonde se revolier. P., 1974. P. 79).

9 Sartre Jean-Paul. Saint-Genet, comedien et martyr. P., 1952. P. 177.
} 


\section{Из архива}

вынести, быть может, желательно, но невозможно, кто бы осмелился бросить в него камень, воздержись он от этого вовсе или возглавь отряды карателей? Или даже переметнись назавтра к своим сегодняшним недругам - разве осудишь его по совести, когда убежден вместе с Сартром, будто мораль есть «мистификация» и «невозможна»? «Историцистское» действие, по Сартру, обнажает свою крайнюю уязвимость не просто с отвлеченно-моралистической точки зрения, но и в свете самих нужд исторического действия, неработоспособного без нравственно осознанной преданности тех, кто в него вовлечен.

Окинув теперь мысленно злоключения Гёца в целом, несложно вскрыть природу окрашенного тоской, натужного и вымученного ${ }^{10}$ сартровского «историцизма». Сама собой выстраивается в уме цепочка уравнений: отсутствие Бога = отсутствию онтологических сущностей = отсутствию нравственных ценностей = отсутствию на историческом поприще поведенческих принципов, выходящих за пределы сугубо ограниченной пользы дела в сложившейся обстановке. Для «историцизма» нет истории как тянущейся издалека и далеко вперед преемственности множества поколений, которая обязывает при определении целей и средств мыслить широко, поверяя свои шаги духовно-нравственным опытом, накопленным народами за века. А есть лишь дробность кратких отрезков с исключительно близлежащими, частичными запросами дня, которые вычленены из сцепления времен и не нуждаются в соотнесенности с чем-то более крупномасштабным, чем они сами по себе. Понятно, что в таком случае личность связана с другими, включая сегодняшних соратников, вчерашних предтеч и завтрашних преемников, узами духовно поверхностными, обедненными, скудными. И по-прежнему склонна ощущать себя внутренне неприкаянной, покинутой. Минуя промежуточные звенья в цепочке отождествлений, она вправе, подобно Гёцу, перескочить от начала прямо к концу, от «смерти Бога» к своему неизбывному одиночеству: «Бог меня не видит, Бог меня не слышит, Бог меня не знает. Ты видишь пустоту над головой: то Бог. Ты видишь щель в двери: то Бог. Ты видишь дыру в земле: то Бог. Бог есть молчание, Бог есть отсутствие. Бог есть одиночество людское». Здесь, как и во всем неверии, продолжающем

10 Что это именно так, не скрывает и сам Сартр. «Позже я расскажу... - обещал он в «Словах», - какие причины заставили меня систематически мыслить наперекор себе, до такой степени наперекор, что чем сильнее досаждало мне мое собственное суждение, тем очевиднее была для меня его истинность». Но и без прямых признаний, пока не обнародованных, о причинах этого мировоззренческого «невроза» нетрудно догадаться по «Дьяволу и Господу Богу». пользоваться христианской «сеткой», подразумевается, что залогом не одиночества может быть лишь допущение Бога - посредника людского братства. «Буду одинок под этими пустыми небесами, - заключает Гёц, - раз нет иного способа быть со всеми». Вытравив немало остаточных родимых пятен веры и в виде ее обмирщенных подстановок (душеспасение через писательство, культуру), и в виде святотатственного богоборчества, Сартр отнюдь не освободился от нее до конца. Для него исчезновение Бога как совершеннейшей полноты бытия знаменует собой воцарение совершенной пустоты бытия. Достаточно, стало быть, выдернуть «священно» - верооткровенную ось, чтобы чувство обязанностей и прав относительно себе подобных, которое как раз и выражается нравственными предписаниями, побудителями, запретами, различением между добром и злом, должным и непозволительным, культурой и варварством, - чтобы все, что совокупно зовется гуманистическими ценностями и целиком не сводимо к одним только насущным деловым требованиям в данных обстоятельствах, оказалось, в свою очередь, обесценено, упразднено.

В результате история помещается в пространстве заведомо внеморальном. И рисуется полем деятельности, где нравственное вменение поступков есть дань пережиткам, несуразность, где оглядка на этический закон - блажь и помеха очередному начинанию. И где даже товарищи по оружию вроде бы ничем, кроме дела, выбранного ими без сколько-нибудь внятных и устойчивых моральных побуждений, не объединены. Выведенная Сартром из «богоутраты» вселенская бесприютность человеческих существ впрямую распространяется и на их жизнечувствие внутри текущей истории. Наметившееся было в «Мертвых без погребения» движение к трагическому гуманизму в «Дьяволе и Господе Боге» пресекается. Ведь умонастроение «смыслоутраты» получает гуманистическую нацеленность и поддерживает ее не иначе как через парадокс, через упрямое «вопреки» - в сопротивлении, напряженном противостоянии немоте сущего. Сартр же, напротив, логик, чересчур безукоризненный логик в переносе бытийного на историческое. И это дает «историцизм» очищенный, без гуманистических противовесов, «вкраплений» или «примесей».

После «Дьявола и Господа Бога» (и окружающих пьесу публицистико-эссеистических сочинений) мечущиеся искатели утраченного смысла исчезают из поля писательского зрения Сартра словно бы в знак того, что им больше нечего делать, незачем терзаться. Задача их самоопределения в жизни как будто разрешена исчерпывающе и бесповоротно. 


\section{Филология: научные исследования 1 (09) • 2013}

Тем не менее еще четверть века без малого, по собственному позднейшему признанию Сартра в книге его бесед с двумя младшими единомышленниками «Бунт - дело правое» (1974), «историцистская» свобода пробивала себе выход в его политико-идеологической деятельности очень туго, лишь «странными и окольными путями» ${ }^{11}$. Причину этого Сартр задним числом усматривает в отсутствии на Западе подходящих общественных сил, готовых взять на вооружение, преломить в своих лозунгах философско-нравственный завет «неукорененных»его театра. И столь, добавим от себя, запутанно-неадекватным выглядело это обнаружение, что в конце 50 -х-60-х годов Сартр слыл скорее гуманистом классической, либеральнодемократической складки, блюстителем общечеловеческих ценностей нравственности и культуры, чем философским провозвестником их пересмотра и отмены. Да и сам он давал поводы к такому мнению, не раз высказываясь, вразрез с заключительными уроками «Дьявола и Господа Бога» и сопутствующих философско-публицистических работ, в том духе, что основная задача левого интеллигента - быть рупором непреложно-жестких требований разума и морали в разноструйно-зыбком историческом потоке. Когда кое-кто из писавших о нем все-таки подмечал глубинную предрасположенность этой мысли к крайностям, могущим обернуться отступлением от гуманизма, соответствующие упреки Сартру встречали обычно удивленно-недоверчивое пожимание плечами: дескать, переусердствовал истолкователь, хватил через край. И только мощная вспышка в мае 1968 г. во Франции молодежно-студенческого бунтарства, которое с первых же дней нашло в лице Сартра одного из своих живых интеллектуальных предтеч и убеленных сединами опекунов, окончательно развеяла недоразумения. Она словно бы указала философу политическое место, действительно и вполне отвечавшее его давним умозрительным разработкам. И он поспешил воспользоваться шедшей ему навстречу возможностью, во всеуслышанье удостоверив, что отныне не причисляет себя к левым интеллигентам «устаревшего» гуманистического замеса. А усматривает свой долг в том, чтобы и самому сделаться «интеллигентом-леваком» и пестовать в этом духе молодую поросль.

Запальчиво-широковещательный мятеж, окрещенный во Франции «гошизмом» («новой левой» — в других странах Запада), если попробовать обозначить вкратце и огрубленно его суть, может быть сведен, в своих наиболее заостренных разновидностях, к

${ }^{11}$ Gavi Ph., Sartre J.-P., Victor P. On a raison de se revolter. P. 17. призывам и потугам сокрушить снизу доверху не просто капиталистическое устройство, но самый уклад выработанной здесь за века цивилизации. Она безоговорочно объявляется насквозь и безнадежно торгашеской, угнетательской, прогнившей, всецело отчуждающей личность и пригодной лишь к отправке на свалку истории. Решительно никакой разницы между культурой, включая сюда трудовые навыки, научные и духовные достижения, обычаи, нравственный опыт поколений, строй мышления, запас знаний и даже техническое умение - с одной стороны, и своекорыстным, извращенным использованием всего этого в рамках буржуазного общества - с другой, подновленное луддитство интеллектуалов, возжаждавших «самоликвидации», не обнаруживало. Прибегнув к языку Гёца, не склонного шалить изысканные уши, позволительно сказать, что межеумочный «ублюдок» норовил совершить на сей раз едва ли не самое черное предательство предательств - отречься от самого себя, от написанных ему на роду духовных запросов и умственных занятий. И, сломав приспособленные для этого инструменты, изменить своему давнему предназначению хранителя и творца духовно-культурных ценностей.

Истоки этого стихийно-анархического, расширительного до безбрежности протеста крылись во вполне законном, но превратно и нелепо осмысленном недовольстве сегодняшних работников умственного труда судьбой, уготованной им там, где духовное творчество низводится до производства прибыли, будь она впрямую вещественно-денежной или охранительно-идеологической. В своей разъяренной слепоте подобное бунтарство принимало за чистую монету то самое понимание культуры и нравственности, какое пытается навязать им господствующий строй, и обрекало их чохом на заклание, поскольку пораженчески считало неспособными сопротивляться извращенному употреблению. На почве такого огульного протеста и состоялась встреча ревнителей безразборной ломки «гуманистического старья» с Сартром. И дело даже не в том самостийном произволе, воплощенном «не», к какому устремлялась сартровская свобода в ее совсем еще раннюю пору, вплоть до «Мух». Подозрительность Сартра-«историциста» времен «Грязных рук» и «Дьявола и Господа Бога» к любым общим ценностям, предлагающим с собою считаться в ходе выполнения освободительных дел в истории, как к чему-то обманчивому, начиненному одной корыстью и вдобавок не имеющему хотя бы малейших бытийноонтологических оснований, сразу же опознавала себя во всенизвергающем экстремизме парижских «леваков». Причем, один из властителей их дум, Сартр оказывал теперь предпочтительное покровительство самым про- 


\section{Из архива}

вокационно-безответственным среди них — «анархомаоистам».

Поистине, логика «смыслоутраты» - коль скоро она пренебрегает спасительным для себя, поворачивающим ее к гуманизму парадоксом и с бестрепетной пря- молинейностью извлекает самые крайние следствия доводится в нынешнем подрывном революционаризме Сартра до весьма опасного абсурда. Сокрушительного если не по намерениям, то по могущим из него вытекать делам.

\section{Сиисок литературы:}

1. Бачелис Т. Интеллектуальные драмы Сартра. М., 1962.

2. Сартр Ж.-П. Пьесы. М., 1967.

3. Сартр Ж.-П. Слова. М., 1964.

4. Beauvoir Simone de. La Force des choses. P., 1963.

5. Gavi Ph., Sartre J.-P., Victor P. On a raisonde se revolier. P., 1974.

6. Gorz A. Fondementspourune morale. P., 1977.

7. Jeanson Fr. Sartre par lui-meme. P., 1955.

8. Sartre Jean-Paul. Saint-Genet, comedien et martyr. P., 1952.

9. Sartre Jean-Paul. Situations III. P., 1949.

10. Sartre Jean-Paul. Theatre. P., 1962.

11. Verstraeten P. Violence el ethique. Esquisse d'une critique de la morale dialectique a partirdu theatre politique de Sartre. P., 1972.

\section{References (transliteration):}

1. Bachelis T. Intellektual nye dramy Sartra. M., 1962.

2. Sartr J.-P. P`esy. M., 1967.

3. Sartr J.-P. Slova. M., 1964.

4. Beauvoir Simone de. La Force des choses. P., 1963.

5. Gavi Ph., Sartre J.-P., Victor P. On a raisonde se revolier. P., 1974.

6. Gorz A. Fondementspourune morale. P., 1977.

7. Jeanson Fr. Sartre par lui-meme. P., 1955.

8. Sartre Jean-Paul. Saint-Genet, comedien et martyr. P., 1952.

9. Sartre Jean-Paul. Situations III. P., 1949.

10. Sartre Jean-Paul. Theatre. P., 1962.

11. Verstraeten P. Violence el ethique. Esquisse d'une critique de la morale dialectique a partirdu theatre politique de Sartre. P., 1972. 